\title{
Arbutin as a Skin Depigmenting Agent with Antimelanogenic and Antioxidant Properties
}

\author{
Yong Chool Boo
}

check for updates

Citation: Boo, Y.C. Arbutin as a Skin Depigmenting Agent with

Antimelanogenic and Antioxidant Properties. Antioxidants 2021, 10, 1129. https://doi.org/10.3390/ antiox10071129

Academic Editors: Irene Dini and Domenico Montesano

Received: 11 June 2021

Accepted: 15 July 2021

Published: 15 July 2021

Publisher's Note: MDPI stays neutral with regard to jurisdictional claims in published maps and institutional affiliations.

Copyright: (C) 2021 by the author. Licensee MDPI, Basel, Switzerland. This article is an open access article distributed under the terms and conditions of the Creative Commons Attribution (CC BY) license (https:/ / creativecommons.org/licenses/by/ $4.0 /)$.
Department of Molecular Medicine, Cell and Matrix Research Institute, BK21 Plus KNU Biomedical Convergence Program, School of Medicine, Kyungpook National University, Daegu 41944, Korea; ycboo@knu.ac.kr; Tel.: +82-53-420-4946

\begin{abstract}
Arbutin is a compound of hydroquinone and D-glucose, and it has been over 30 years since there have been serious studies on the skin lightening action of this substance. In the meantime, there have been debates and validation studies about the mechanism of action of this substance as well as its skin lightening efficacy and safety. Several analogs or derivatives of arbutin have been developed and studied for their melanin synthesis inhibitory action. Formulations have been developed to improve the stability, transdermal delivery, and release of arbutin, and device usage to promote skin absorption has been developed. Substances that inhibit melanin synthesis synergistically with arbutin have been explored. The skin lightening efficacy of arbutin alone or in combination with other active ingredients has been clinically evaluated. Combined therapy with arbutin and laser could give enhanced depigmenting efficacy. The use of arbutin causes dermatitis rarely, and caution is recommended for the use of arbutin-containing products, especially from the viewpoint that hydroquinone may be generated during product use. Studies on the antioxidant properties of arbutin are emerging, and these antioxidant properties are proposed to contribute to the skin depigmenting action of arbutin. It is hoped that this review will help to understand the pros and cons of arbutin as a cosmetic ingredient, and will lead to future research directions for developing advanced skin lightening and protecting cosmetic products.
\end{abstract}

Keywords: arbutin; melanin; pigment; melasma; skin lightening; cosmetic; hyperpigmentation; tyrosinase; antioxidant; nuclear factor erythroid 2-related factor 2 (Nrf2)

\section{Introduction}

Hydroquinone (Chemical structure 1, Figure 1) at concentrations varying from 2 to $5 \%$ has been prescribed as the primary therapy for hyperpigmentation disorders including melasma [1,2]. It is used alone or in combination with other active pharmaceutical ingredients, such as retinoids and steroids, for added benefits [3,4]. Hydroquinone not only inhibits tyrosinase (TYR) activity and destroys melanosomes, but also causes necrosis of melanocytes by modifying the membrane structure [5]. This is the potential mechanism of action of hydroquinone as a skin lightening agent as well as its toxicity mechanism. The use of this ingredient in cosmetics has been banned since 2001 because of the high risk of carcinogenesis in case of prolonged exposure to hydroquinone [6,7].

Arbutin (Chemical structure 2, Figure 1) is a compound with a structure in which one molecule of D-glucose is bound to hydroquinone. D-glucose exists in $\alpha$, $\beta$, or $\gamma$-anomeric form in aqueous solution, with $\beta$-anomer being a dominant form. $\beta$-Arbutin (this stereoisomer is called arbutin) in which the $\beta$-anomer of D-glucose is bound to hydroquinone is mainly found in plants, such as wheat, pear, and bearberry [8]. $\alpha$-arbutin (Chemical structure 3 , Figure 1) is a compound of hydroquinone and the $\alpha$-anomer of D-glucose [9]. It has been about 30 years since arbutin was studied in earnest to use as a hydroquinone alternative for skin lightening purposes [10]. It is thus timely to investigate the accumulated information on the efficacy and safety of arbutin and its mechanism of action. 


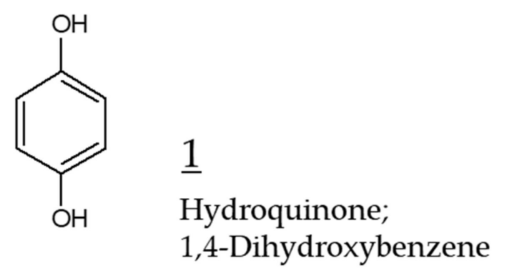

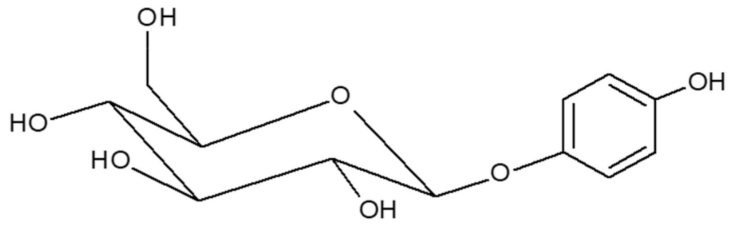

$\underline{2}$

Arbutin;

$\beta$-Arbutin;

Hydroquinone $\beta$-D-glucose;

Hydroquinone $\beta$-D-glucopyranoside;

4-Hydroxyphenyl $\beta$-D-glucopyranoside
$\alpha$-Arbutin;

Hydroquinone $\alpha$-D-glucose; Hydroquinone $\alpha$-D-glucopyranoside; 4-Hydroxyphenyl $\alpha$-D-glucopyranoside

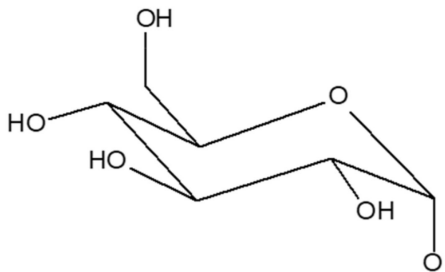

${ }_{\mathrm{OH}}^{1}$

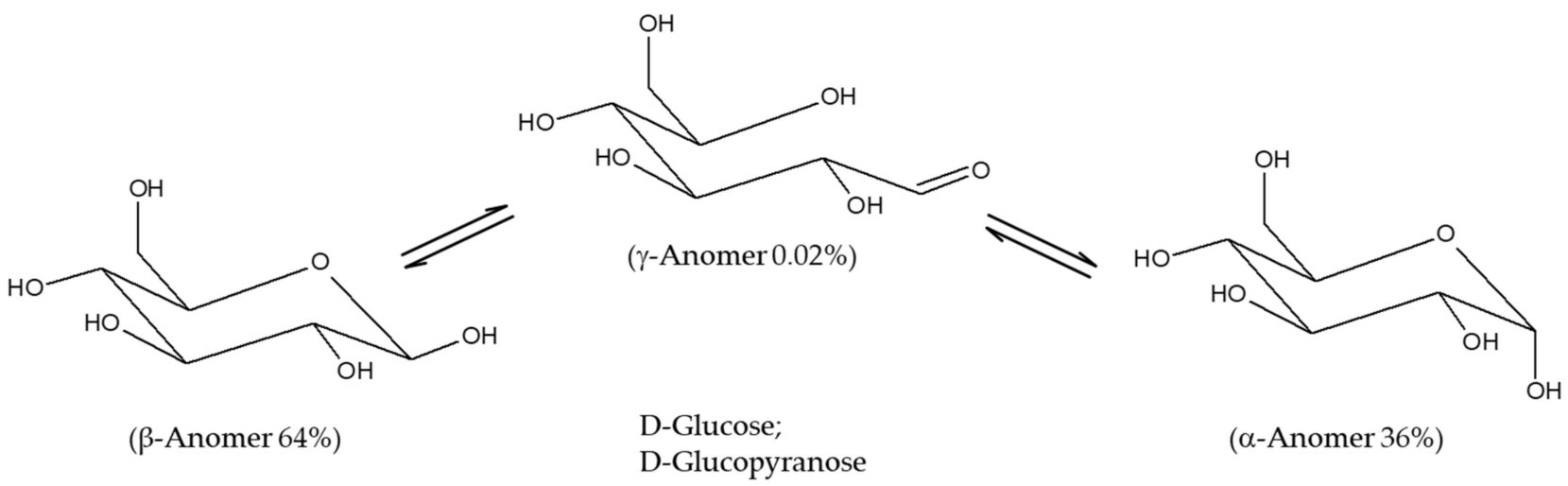

Figure 1. Chemical structures of hydroquinone, arbutin ( $\beta$-arbutin), and $\alpha$-arbutin. Anomeric structures of D-glucose are also shown for comparative purposes.

In this review, we will try to get answers to questions that have been controversial. The questions are as follows. Which arbutin or $\alpha$-arbutin is more advantageous as a skin lightening agent? Do arbutin and $\alpha$-arbutin have properties of inhibiting melanin synthesis without releasing hydroquinone? Is the toxicity of arbutin due to the release of hydroquinone?

There are other important questions to be answered. Is there a substance with a similar structure with more advantageous properties than arbutin? Could it be possible to increase the skin absorption efficiency of arbutin by a formulation or device-assisted method? Do clinical trial results support the skin lightening benefits of arbutin outweighs its potential harmful risks? What are the side effects of arbutin when applied to the skin? Do the antioxidant properties of arbutin and or $\alpha$-arbutin contribute to their skin depigmenting action? Can arbutin be applied to skin disorders other than hyperpigmentation?

We hope that this review will help you find answers to these questions. It is also hoped that this review will help identify the pros and cons of arbutin as an active cosmetic ingredient, improve our understanding of its mechanism of action, and set the direction for future research on its cosmetic applications. 


\section{Modulation of Melanin Synthesis}

\subsection{Pigmentation and Melanin}

Melanin is a polymeric, colored pigment distributed throughout the skin, hair, eye, and other tissues. It is synthesized in melanosomes, unique organelles located in epidermal melanocytes, and plays key roles in maintaining skin homeostasis [11,12], and photoprotection $[13,14]$. Dysregulated melanin metabolism results in skin pigmentary disorders, such as hyperpigmentation and hypopigmentation [15-17]. The melanocytes derived from individuals with different skin colors show different melanogenic activity although the distribution density of melanocytes in the skin is not much different $[18,19]$. There was a close association between the melanogenic activity of melanocytes and skin color in humans $[20,21]$.

\subsection{Regulation of Melanin Synthesis}

Melanin synthesis is influenced by diverse factors including genetic background, epigenetic adaptation, hormonal changes, nutritional status, and environmental conditions [22,23]. For example, proopiomelanocortin-derived peptide hormones, such as $\alpha$ melanocyte-stimulating hormone (MSH), $\beta-\mathrm{MSH}$, and adrenocorticotrophic hormone, act as agonists of the melanocortin 1 receptor, a $\mathrm{G}$ protein-coupled receptor, and stimulate protein kinase A-mediated signaling pathway leading to the activation of cAMP response element-binding protein (CREB). [22,24]. In the nucleus, the active CREB binds to the cAMP response element on the promoter of microphthalmia-associated transcription factor (MITF), inducing transcription of the target gene $[25,26]$. MITF plays a key role in the regulation of melanin synthesis by regulating gene expression of melanogenic enzymes, including TYR, tyrosinase-related protein-1 (TYRP-1), and tyrosinase-related protein-2 (TYRP-2) [22,24]. MITF can also be activated by the stem cell factor/receptor tyrosine kinase protein c-Kit/mitogen-activated protein kinases pathway, and Wnt/frizzled/glycogen synthase kinase $3 \beta / \beta$-catenin pathway $[27,28]$. Other signaling pathways, such as phospholipase $C$ /diacylglycerol/protein kinase $C \beta$ cascade, and nitric oxide/cGMP/protein kinase $\mathrm{G}$ cascade also can regulate melanin synthesis $[29,30]$. For more details, please refer to other reviews on autocrine and paracrine regulation and cell signaling pathways associated with melanogenesis [30,31].

\subsection{Melanin Synthesis Pathway}

Melanin synthesis begins with the oxidation of L-tyrosine to DOPAquinone by monophenolase activity of TYR or the oxidation of L-3,4-dihydroxyphenylalanine (DOPA) to DOPAquinone by diphenolase activity of TYR [32-35]. DOPAquinone reacts with cysteine to produce 5-S-cysteinylDOPA or 2-S-cysteinylDOPA and enters the pheomelanin synthesis pathway. These two compounds are oxidized to quinones and through intramolecular cyclization, and benzothiazine and benzothiazole intermediates are produced. These intermediates are used as building blocks to synthesize the reddish-yellow polymer pheomelanin [36]. Alternatively, when DOPAquinone is oxidized to DOPAchrome via leukoDOPAchrome, it enters the eumelanin synthesis pathway. DOPAchrome is converted to 5,6-dihydroxyindole-2-carboxylic acid (DHICA) by DOPAchrome tautomerase activity of TYRP-2 or to 5,6-dihydroxyindole (DHI) by releasing $\mathrm{CO}_{2}$. DHICA and DHI are oxidized to quinones by the DHICA oxidase activity of TYRP-1, and the DHI oxidase activity of TYR, respectively, and these are used as building blocks to synthesize the brownish-black polymer eumelanin [37].

\subsection{Artificial Modulation of Melanogenesis}

TYR-catalyzed enzyme reactions constitute key steps in the biosynthetic routes for melanin, and thus, the enzyme provides a useful target for the pharmacological control of skin hyper- and hypo-pigmentation in dermatology and cosmetology [38,39]. Gene expression of TYR could be enhanced or suppressed via pharmacological approaches $[14,40]$. Various synthetic and natural compounds are known to inhibit the catalytic activity of TYR in vitro [41-43]. For some active ingredients, the skin depigmenting efficacy was verified 
through clinical trials [44-48]. Various depigmenting active ingredients including arbutin are used in cosmetics [49].

\section{Arbutin}

\subsection{Anti-Melanogenic Effect of Arbutin}

Arbutin has the effect of reducing melanin content at a concentration that has little effect on the viability of cultured human melanocytes. Maeda et al. showed that arbutin dose-dependently reduced TYR activity in human melanocytes at concentrations between 0.1 and $1.0 \mathrm{mM}$ without significantly decreasing cell viability, and its inhibitory effect against cellular melanin synthesis was more potent than that of kojic acid or L-ascorbic acid when compared at a fixed concentration $(0.5 \mathrm{mM})$ [50]. Akiu et al. reported that the melanin content of cultured murine melanoma B16 cells was reduced by arbutin, and the effect was explained by the decrease in intracellular TYR activity [10]. Arbutin was shown to inhibit melanin production in B16 cells stimulated by $\alpha$-MSH and abrogate the hyperpigmentation effects of $\alpha$-MSH in brownish guinea pig and human skin explants in organ culture experiments [51].

The decrease in TYR activity in human melanocytes by arbutin does not appear to be due to the decrease in the expression level of this enzyme. Maeda et al. reported that arbutin at $0.5 \mathrm{mM}$ reduced the activity of intracellular TYR by $50 \%$ but did not affect the mRNA expression level of TYR [52]. Chakraborty et al. showed that arbutin $(0.37 \mathrm{mM})$ lowered cellular melanin content but did not reduce the protein levels of TYR, TYRP-1, and TYRP-2 [53]. If so, arbutin may inhibit post-translational modification or maturation of newly synthesized TYR or may induce irreversible inactivation of already synthesized mature TYR. In an experiment in which lysates obtained from human melanocytes treated with $1.0 \mathrm{mM}$ arbutin or not were analyzed by zymography, the TYR activity was reduced to $87 \%$ in the former [52]. Therefore, it is reasonable to consider arbutin as an inactivator of cellular TYR, rather than a suppressor of TYR gene expression.

In an in vitro assay using crude protein extracts derived from murine melanoma B16 cells, arbutin was shown to be able to directly inhibit the catalytic activity of TYR [10]. In the experiment with mushroom TYR, when L-DOPA was used as a substrate, arbutin showed a lower inhibitory effect than kojic acid and L-ascorbic acid: Their 50\% inhibitory $\left(\mathrm{IC}_{50}\right)$ values were $10 \mathrm{mM}, 0.12 \mathrm{mM}$, and $0.2 \mathrm{mM}$, respectively [52]. In the experiment using human TYR (derived from melanocytes of Asian neonatal foreskins), when either L-tyrosine (for monophenolase activity) or L-DOPA (for diphenolase activity) were used as substrates, the $\mathrm{IC}_{50}$ values of arbutin were $5.7 \mathrm{mM}$ and $18.9 \mathrm{mM}$, respectively: Arbutin appeared to be an inhibitor in a competitive relationship with L-tyrosine [52]. It is presumed that arbutin competes with a structurally similar substrate to bind to the active site of the TYR enzyme. More importantly, the concentration at which arbutin inhibits the catalytic activity of TYR in vitro is higher than the concentration that reduces cellular melanin, so there is no conviction as to whether this mechanism works in the cell.

It has been reported that arbutin can also act as a substrate for TYR. In the presence of a catalytic amount of L-DOPA as a cofactor, arbutin is oxidized by mushroom TYR to produce 3,4-dihydroxyphenyl-O-beta-D-glucopyranoside [54]. During the catalysis, the TYR enzyme exists as $E_{\text {met }}, E_{\text {deoxy }}$, and $E_{\text {oxy }}$ forms that are mutually converted [34] (Figure 2). $\mathrm{E}_{\text {deoxy }}$ binds oxygen to form $\mathrm{E}_{\mathrm{oxy}}$ that can capture a monophenol (M) or diphenol (D) substrate. When $E_{\text {oxy }}$ encounters an $M$ substrate, $E_{o x y}-M$ is formed and it is converted to $E_{m e t}-D$ that releases a quinone $(Q)$ product and regenerates $E_{\text {deoxy, }}$ completing the monophenolase cycle. If $E_{o x y}$ encounters a $D$ substrate, $E_{o x y}-D$ is formed and then releases a $Q$ product and $E_{m e t}$. $E_{m e t}$ can bind to another $D$ substrate, forming $E_{m e t}-D$ that releases a $\mathrm{Q}$ product and $\mathrm{E}_{\text {deoxy, }}$ completing the monophenolase cycle. $\mathrm{E}_{\text {deoxy }}$ proceeds to the next cycles. However, in the absence of D substrates, $E_{\text {met }}$ binds to a monophenol inhibitor (I), and this results in a dead-end pathway, causing the inactivation of the enzyme. Arbutin is considered to be able to inactivate the TYR enzyme by binding with $E_{\text {met }}$ under L-DOPA-deficient conditions [55]. 


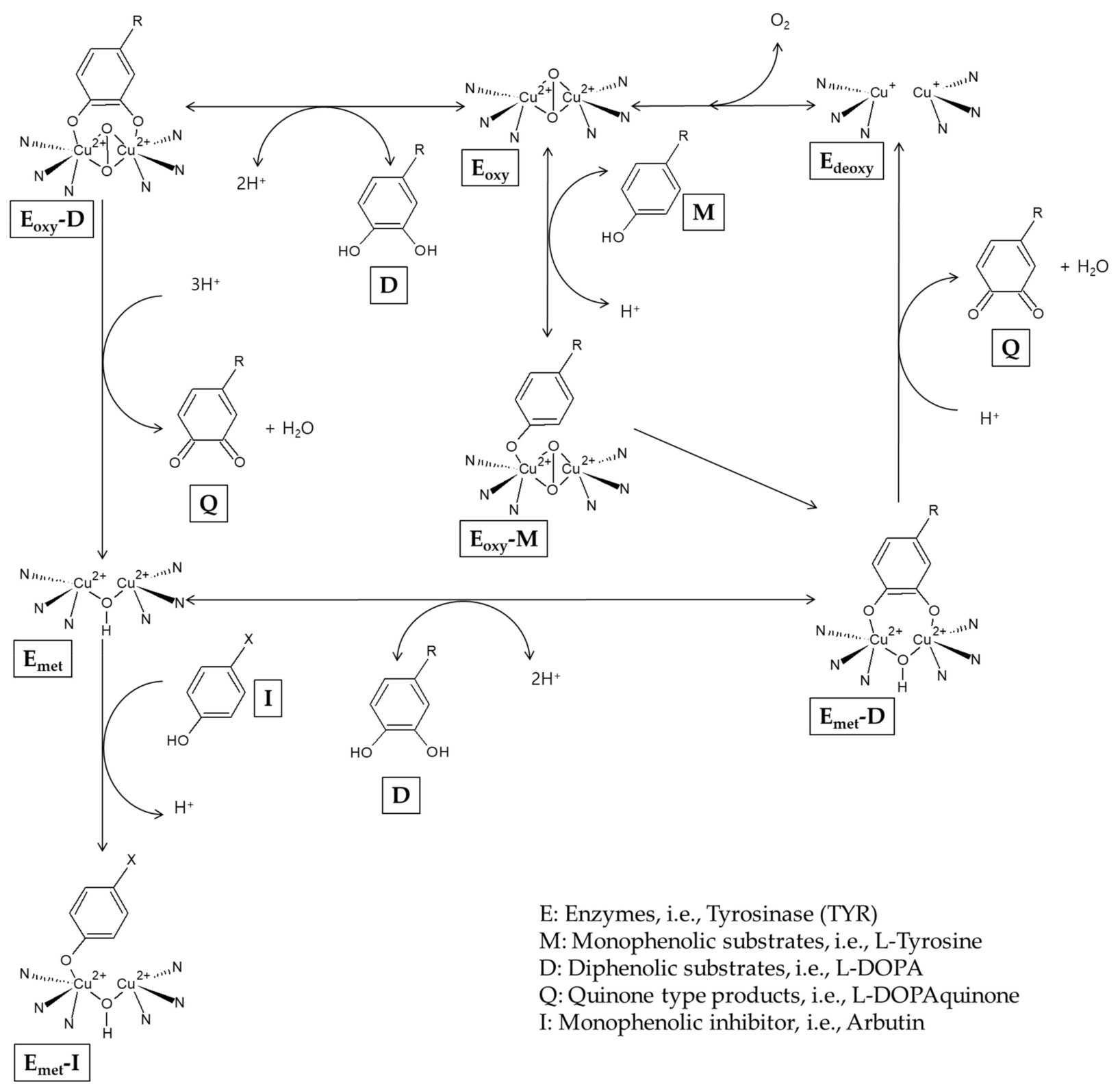

Figure 2. A potential mechanism for the inactivation of tyrosinase by arbutin.

Inoue et al. compared the effects of hydroquinone and arbutin on the differentiation of melanocytes [56]. The results showed that hydroquinone downregulated the early stage of differentiation of mouse embryonic stem cells to neural crest cells, and the late stage of differentiation to melanocytes with melanogenic capability. On the other hand, arbutin did not affect the early and late stages of differentiation of melanocytes and only suppressed elevations in TYR expression in the late stage of differentiation.

\subsection{A Possible Production of Hydroquinone from Arbutin}

There is a disagreement over whether arbutin works by being decomposed into hydroquinone and glucose or not. Akiu et al. stated that the decomposition of arbutin in the cell suspension could not be observed [10]. However, as shown in the experiment of Maeda et al., hydroquinone can reduce the activity of intracellular TYR by $50 \%$ at a concentration 100 times lower than arbutin [50,52]. When arbutin is added to cosmetic products, hydroquinone can be produced to a different level depending on storage conditions [57,58]. In addition, when arbutin is applied to the skin, hydroquinone can be produced by ex- 
posure to skin microorganisms [59] or ultraviolet radiation (UVR) [60]. Therefore, there remains a possibility that a small amount of hydroquinone, which may be produced as a decomposition product of arbutin, contributes to the inhibition of melanin synthesis or the inactivation of TYR in cells. Nevertheless, the majority of evidence supports that arbutin has intrinsic properties that inhibit cellular melanogenesis and reduce cellular TYR activity regardless of hydroquinone release.

\subsection{Pro-Melanogenic Effect of Arbutin}

There is another report that conflicts with many other studies that have reported the melanin-lowering action of arbutin. Nakajima et al. observed that in cultured normal human melanocytes (from neonatal Caucasian foreskins) treated with increasing concentrations of arbutin, the pigmentation became darker (effective concentrations, 2-8 $\mathrm{mM}$ ), whereas the viability $(2-8 \mathrm{mM})$ and the TYR activity $(0.5-4 \mathrm{mM})$ of the cells decreased [61]. One possible explanation for the particular observation is that arbutin increases the synthesis of intracellular melanin by acting as a substrate of TYR as discussed above. Another possibility is that although arbutin inhibits the synthesis of new melanin, it blocks the release of synthesized melanin out of the cell, thereby causing the accumulation of melanin inside cells. Melanosome transfer is a unique biological process that delivers a package of organelles from melanocytes to keratinocytes [62], and various mechanisms, such as cytophagocytosis, membrane fusion, shedding-phagocytosis, and exocytosis-endocytosis, have been proposed to explain this process [63].

\subsection{Preparation of Arbutin}

Arbutin can be prepared by various methods, such as extraction from plants, bioconversion from hydroquinone, and chemical synthesis [64,65]. The content of arbutin in a plant varies depending on the species, parts of the plant, development stages, and harvest season $[66,67]$. The production efficiency for arbutin also varies depending on the extraction and purification methods [68-70].

Fermentation of soybeans with certain strains of Bacillus subtilis was shown to produce arbutin and other TYR inhibitory compounds [71]. Shang et al., engineered a yeast, Yarrowia lipolytica, to produce arbutin by expressing three exogenous genes, such as chorismate pyruvate lyase, 4-hydroxybenzoate 1-hydroxylase, and hydroquinone glucosyltransferase [72]. The engineered Y. lipolytica was capable of de novo biosynthesis of arbutin through the shikimate pathway.

\section{4. $\alpha$-Arbutin}

\subsection{Preparation of $\alpha$-Arbutin}

$\alpha$-arbutin could be produced through transglycosylation from various glucose donors to hydroquinone catalyzed by purified enzymes. Sucrose phosphorylase from Leuconostoc mesenteroides [73], $\alpha$-amylase from Bacillus subtilis X-23 [74], sucrose isomerase from Erwinia rhapontici [75], amylosucrase from Deinococcus geothermalis [76] and Cellulomonas carboniz T26 [77], and cyclodextrin glucanotransferase from Thermoanaerobacter sp. [78] were capable of $\alpha$-arbutin synthesis.

Kurosu et al. synthesized $\alpha$-arbutin through fermentation of Xanthomonas campestris WU-9701 [79], Xanthomonas CGMCC, and Xanthomonas BT-112 [80,81]. Wu et al. developed a fed-batch culture strategy for the production of $\alpha$-arbutin using recombinant Escherichia coli cells anchoring surface-displayed transglucosidase as a whole-cell biocatalyst and lactose as an inducer of the recombinant protein [82]. $\alpha$-arbutin can be chemically synthesized via an approach similar to that for arbutin $[83,84]$.

\subsection{Anti-Melanogenic Effect of $\alpha$-Arbutin}

Many studies have compared the inhibitory effects of arbutin ( $\beta$-arbutin) and $\alpha$ arbutin on TYR catalytic activity in an in vitro experiment, with inconsistent results (Table 1). Kiato et al. reported that $\alpha$-arbutin inhibited monophenolase activity of mush- 
room TYR with potency slightly lower than arbutin or hydroquinone [73]. Funayama et al. reported that $\alpha$-arbutin inhibited diphenolase activity of TYR derived from murine melanoma 10 times more potently than $\beta$-arbutin, and their $\mathrm{IC}_{50}$ values were $0.48 \mathrm{mM}$ and $4.8 \mathrm{mM}$, respectively [85]. On the other hand, the inhibitory effect against mushroom TYR diphenolase was not observed in the case of $\alpha$-arbutin, unlike $\beta$-arbutin $\left(\mathrm{IC}_{50}, 8.4 \mathrm{mM}\right)$. Later, Qin et al. reported that $\alpha$-arbutin inhibited monophenolase activity $\left(\mathrm{IC}_{50}, 4.5 \mathrm{mM}\right)$, whereas it activated diphenolase activity of mushroom TYR [86].

Table 1. Tyrosinase inhibitory effects of arbutin and $\alpha$-arbutin.

\begin{tabular}{|c|c|c|c|c|}
\hline \multirow[b]{2}{*}{ Literature } & \multirow[b]{2}{*}{ Compounds } & \multicolumn{2}{|c|}{ Tyrosinase Inhibitory Effects } & \multirow[b]{2}{*}{ Enzymes and Substrates Used } \\
\hline & & Monophenolase Activity & $\begin{array}{l}\text { Diphenolase } \\
\text { Activity }\end{array}$ & \\
\hline \multirow{3}{*}[73]{} & Hydroquinone & $97.2 \%$ inhibition at $3 \mathrm{mM}$ & & \multirow{3}{*}{$\begin{array}{l}\text { Mushroom tyrosinase; } \\
0.3 \text { mM L-tyrosine }\end{array}$} \\
\hline & Arbutin & $82.0 \%$ inhibition at $3 \mathrm{mM}$ & & \\
\hline & $\alpha$-arbutin & $72.8 \%$ inhibition at $3 \mathrm{mM}$ & & \\
\hline \multirow{4}{*}[85]{} & $\alpha$-arbutin & & $\mathrm{IC}_{50}=0.48 \mathrm{mM}$ & \multirow{2}{*}{$\begin{array}{l}\text { B16 mouse tyrosinase; } \\
3.3 \mathrm{mM} \text { L-DOPA }\end{array}$} \\
\hline & Arbutin & & $\mathrm{IC}_{50}=4.8 \mathrm{mM}$ & \\
\hline & $\alpha$-arbutin & & No inhibition & \multirow{2}{*}{$\begin{array}{l}\text { Mushroom tyrosinase; } \\
0.83 \text { mM L-DOPA }\end{array}$} \\
\hline & Arbutin & & $\mathrm{IC}_{50}=8.4 \mathrm{mM}$ & \\
\hline \multirow{2}{*}{ [87] } & $\alpha$-arbutin & $\mathrm{IC}_{50}=8 \mathrm{mM}$ & $\mathrm{IC}_{50}=8.87 \mathrm{mM}$ & \multirow{2}{*}{$\begin{array}{c}\text { Mushroom tyrosinase; } 0.25 \mathrm{mM} \\
\text { L-tyrosine plus } 0.01 \mathrm{mM} \text { L-DOPA for } \\
\text { monophenolase activity; } \\
0.5 \mathrm{mM} \text { L-DOPA for diphenolase activity }\end{array}$} \\
\hline & Arbutin & $\mathrm{IC}_{50}=0.9 \mathrm{mM}$ & $\mathrm{IC}_{50}=0.7 \mathrm{mM}$ & \\
\hline
\end{tabular}

Garcia-Jimenez et al. demonstrated that both $\alpha$ and $\beta$-arbutin are apparent competitive inhibitors against both the monophenolase and diphenolase activities of TYR [87]. In their study, $\mathrm{IC}_{50}$ values of $\beta$-arbutin for TYR monophenolase and diphenolase activities were 0.9 and $0.7 \mathrm{mM}$, respectively, which were much lower than those for $\alpha$-arbutin $\left(\mathrm{IC}_{50}, 8.0\right.$ and $8.87 \mathrm{mM}$ for TYR monophenolase and diphenolase activities, respectively). They also kinetically characterized $\alpha$ and $\beta$-arbutin as substrates of TYR and obtained their Michaelis constant values of $6.5 \mathrm{mM}$ and $3.0 \mathrm{mM}$, respectively, supporting that the TYR enzyme has a higher affinity for $\beta$-arbutin than $\alpha$-arbutin.

As such, contradictory results have been reported regarding which arbutin or $\alpha$ arbutin is a more potent TYR inhibitor. The causes for this extreme inconsistency between studies are not clear and it is only assumed that the inconsistent results may be due to differences in the origin and purity of the enzyme, the conformational state of the enzyme, the type and concentration of substrates, oxygen concentration, $\mathrm{pH}$, temperature, the purity of arbutin and $\alpha$-arbutin, and the possibility of hydroquinone contamination or production. A conclusion could be reached if several institutions conduct studies comparing the activity of the same substances under standardized experimental conditions.

The antimelanogenic effects of $\alpha$-arbutin were reported by Sugimoto et al. [88]. They showed that $\alpha$-arbutin decreased melanin content and TYR activity in cultured human melanoma cells, at a concentration below $1.0 \mathrm{mM}$, without significant effects on cell growth and TYR mRNA level. They further showed that treatment of the human skin model with $\alpha$-arbutin (250 $\mu \mathrm{g}$ per tissue) reduced melanin content to a $40 \%$ level of the control, without causing cell death.

\section{Other Related Compounds}

\subsection{Glycosidic Derivatives of Arbutin and $\alpha$-Arbutin}

Various glycosidic derivatives of arbutin and $\alpha$-arbutin, which have additional molecules of glucose, were synthesized through a biological process (Table 2, Figure 3). It is interesting to note that their TYR inhibitory effects are different depending on the structure. However, they have a disadvantage in that the molecular weight is too large for industrial use. 
Table 2. Tyrosinase inhibitory effects of arbutin and $\alpha$-arbutin and their glucosides.

\begin{tabular}{|c|c|c|c|c|c|}
\hline \multirow{2}{*}{ Literature } & \multicolumn{2}{|l|}{ Compounds } & \multicolumn{2}{|c|}{ Tyrosinase Inhibitory Effects } & \multirow{2}{*}{$\begin{array}{l}\text { Enzymes and } \\
\text { Substrates Used }\end{array}$} \\
\hline & Name & Chemical Structure & $\begin{array}{l}\text { Monophenolase } \\
\text { Activity }\end{array}$ & $\begin{array}{l}\text { Diphenolase } \\
\text { Activity }\end{array}$ & \\
\hline \multirow{4}{*}{ [89] } & $\alpha$-arbutin & 3 & & $\mathrm{IC}_{50}=2.1 \mathrm{mM}$ & \multirow{4}{*}{$\begin{array}{c}\text { Human tyrosinase; } \\
3.3 \mathrm{mM} \text { L-DOPA }\end{array}$} \\
\hline & Arbutin & 2 & & $\mathrm{IC}_{50}>30 \mathrm{mM}$ & \\
\hline & 4-Hydroxyphenyl $\beta$-maltoside & 7 & & $\mathrm{IC}_{50}=5.7 \mathrm{mM}$ & \\
\hline & 4-Hydroxyphenyl $\beta$-maltotrioside & 8 & & $\mathrm{IC}_{50}=6.1 \mathrm{mM}$ & \\
\hline \multirow{2}{*}{ [90] } & 4-Hydroxyphenyl $\alpha$-maltoside & 11 & & $\mathrm{IC}_{50}=4.9 \mathrm{mM}$ & \multirow{2}{*}{$\begin{array}{c}\text { Human tyrosinase; } \\
\text { 3.3 mM L-DOPA }\end{array}$} \\
\hline & 4-Hydroxyphenyl $\alpha$-maltotrioside & 12 & & $\mathrm{IC}_{50}=13.9 \mathrm{mM}$ & \\
\hline \multirow{3}{*}{ [91] } & Arbutin & 2 & & $\mathrm{~K}_{\mathrm{i}}=2.8 \mathrm{mM}$ & \multirow{3}{*}{$\begin{array}{c}\text { Mushroom } \\
\text { tyrosinase; } \\
3.3 \mathrm{mM} \text { DOPA }\end{array}$} \\
\hline & 4-Hydroxyphenyl $\beta$-isomaltoside & 9 & & $\mathrm{~K}_{\mathrm{i}}=3.7 \mathrm{mM}$ & \\
\hline & 4-Hydroxyphenyl $\beta$-isomaltotrioside & 10 & & Not determined & \\
\hline \multirow{5}{*}{ [92] } & Arbutin & 2 & $\mathrm{IC}_{50}=6 \mathrm{mM}$ & & \multirow{5}{*}{$\begin{array}{c}\text { Mushroom } \\
\text { tyrosinase; } \\
0.03 \% \text { L-tyrosine }\end{array}$} \\
\hline & $\beta$-D-Glucopyranosyl-( $(1 \rightarrow 6)$-arbutin & 4 & $\mathrm{IC}_{50}=8 \mathrm{mM}$ & & \\
\hline & $\beta$-D-Glucopyranosyl- $(1 \rightarrow 4)$-arbutin & 5 & $\mathrm{IC}_{50}=10 \mathrm{mM}$ & & \\
\hline & $\beta$-D-Glucopyranosyl-( $(1 \rightarrow 3)$-arbutin & 6 & $\mathrm{IC}_{50}=5 \mathrm{mM}$ & & \\
\hline & $\alpha$-D-Glucopyranosyl-( $(1 \rightarrow 4)$-arbutin & 7 & $\mathrm{IC}_{50}=5 \mathrm{mM}$ & & \\
\hline \multirow{4}{*}{ [93] } & $\alpha$-arbutin & 3 & & $\mathrm{IC}_{50}=2.1 \mathrm{mM}$ & \multirow{4}{*}{$\begin{array}{l}\text { Human tyrosinase; } \\
3 \text { mM L-DOPA }\end{array}$} \\
\hline & $\alpha$-arbutin- $\alpha$-glucoside & 11 & & $\mathrm{IC}_{50}=6.9 \mathrm{mM}$ & \\
\hline & $\alpha$-arbutin- $\alpha$-maltoside & 12 & & $\mathrm{IC}_{50}=15.6 \mathrm{mM}$ & \\
\hline & $\alpha$-arbutin- $\alpha$-maltotrioside & 13 & & Not determined & \\
\hline
\end{tabular}

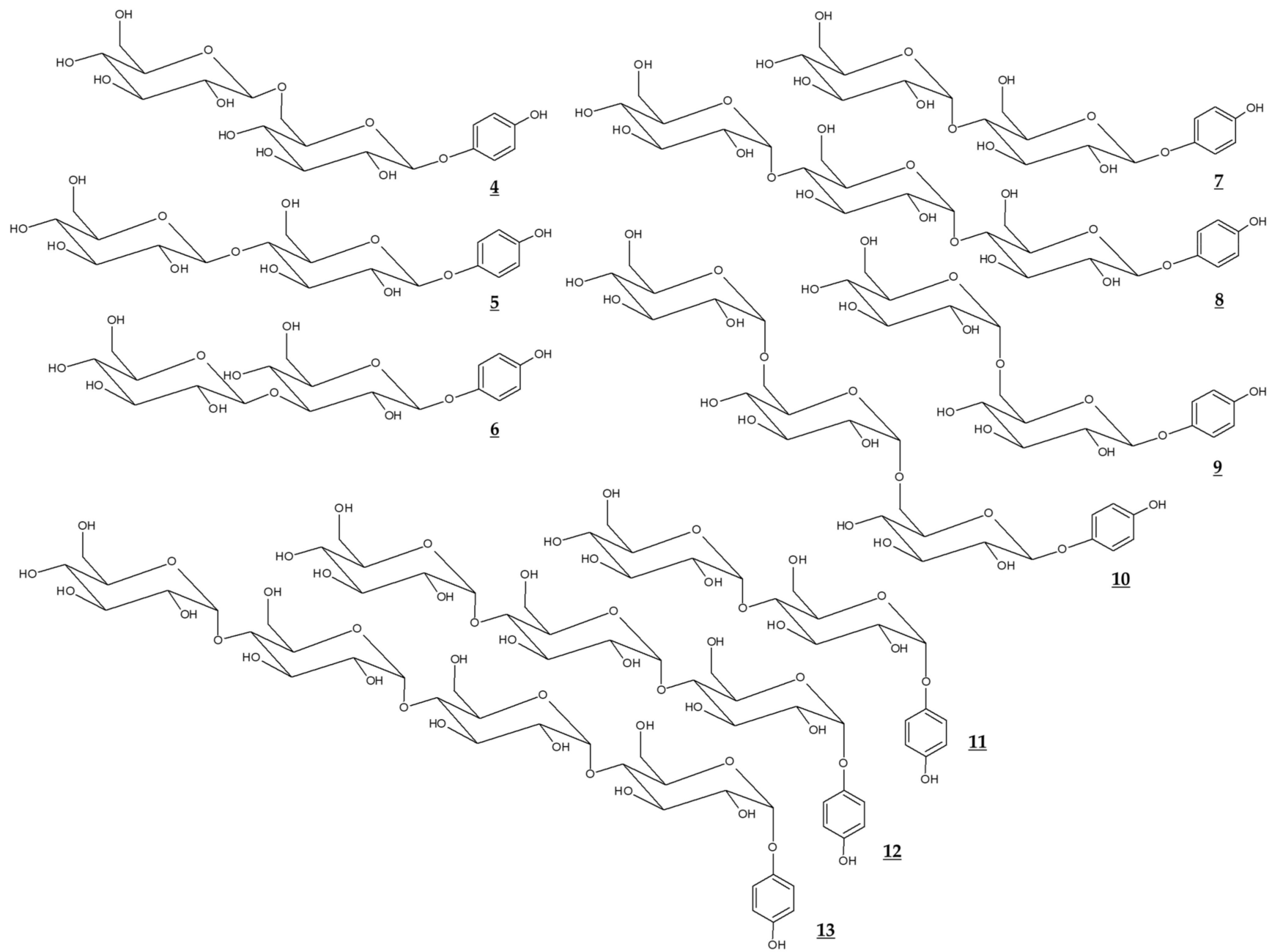

Figure 3. Chemical structures of glucosides of arbutin and $\alpha$-arbutin. 


\subsection{Esters of Arbutin}

Jiang et al. compared the effects of arbutin and acetylated arbutin (Chemical structure 14, Figure 4) on cell viability, apoptosis, and migration as well as melanin synthesis capacity [94]. After a $24 \mathrm{~h}$ treatment at $5.4 \mathrm{mM}$, both arbutin and acetylated arbutin reduced cell viability and melanogenic capacity, induced cell apoptosis, G1 cell cycle arrest, and mitochondrial disruption in B16 murine melanoma cells, with the latter compound being more effective.
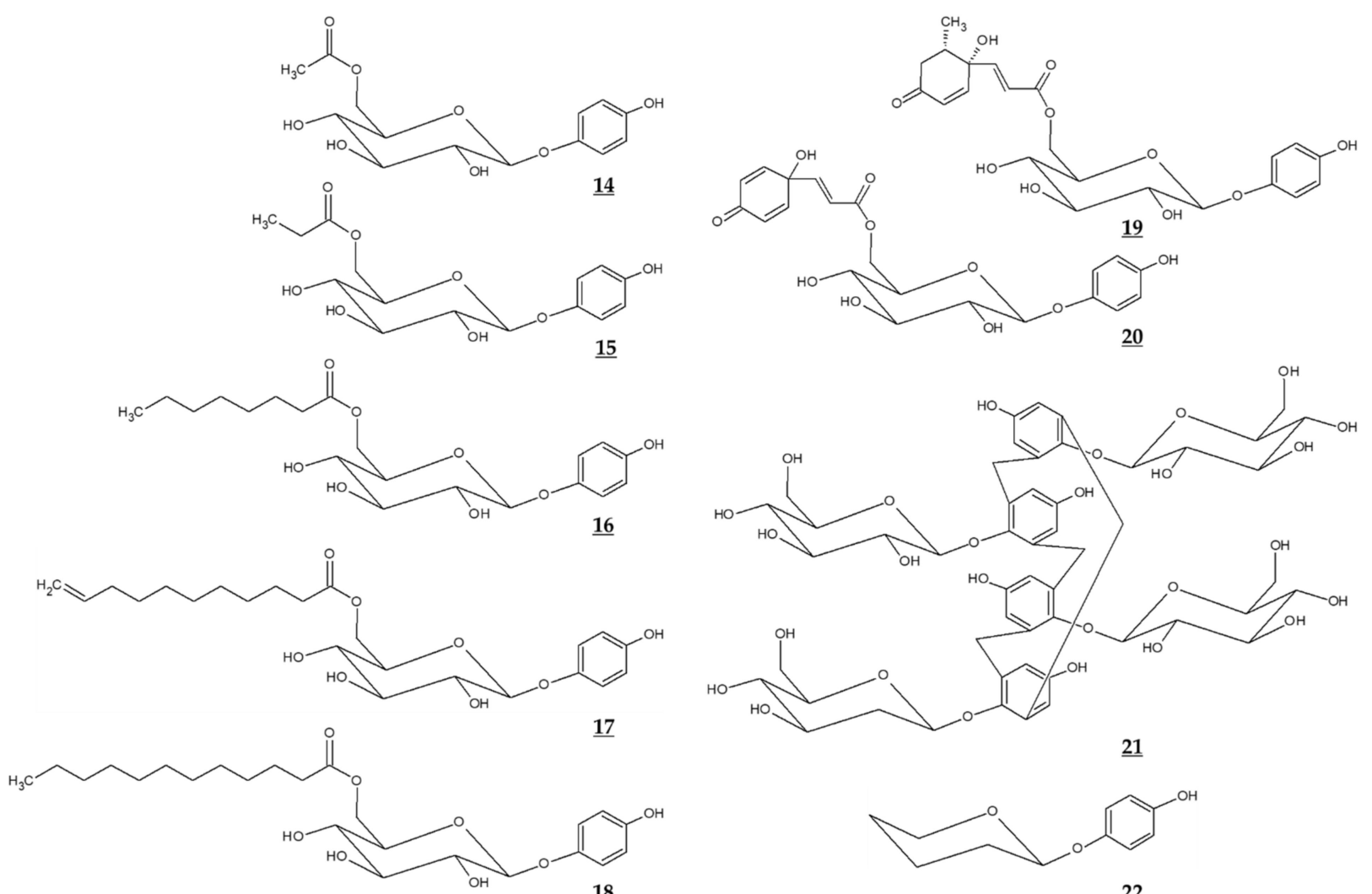

$\underline{22}$

Figure 4. Chemical structures of various derivatives of arbutin and related compounds.

Various ester compounds of arbutin were also synthesized or extracted from plants, and some of them had TYR inhibitory effects or cell melanin synthesis inhibitory effects (Table 3, Figure 4). In particular, arbutin undecylenic acid ester (Chemical structure 17, Figure 4) was shown to be a more potent inhibitor of TYR than arbutin in several studies [95-97]. It is hoped to evaluate its skin lightening efficacy through in vivo studies or clinical trials.

Yamashita-Higuchi et al. isolated arbutin derivatives and related compounds from the leaves of Grevillea robusta [98]. Several compounds, such as grevilloside M and robustaside, showed potent antimelanogenic effects in B16 cells. These compounds were considered to inhibit melanin synthesis without involving TYR inhibition.

\subsection{Calixarbutin}

Ghaffarzadeh et al. synthesized calixarbutin (Chemical structure 21, Figure 4), a cyclic tetramer of arbutin that inhibits mushroom TYR activity and proliferation of A375 human malignant melanoma cell line, more potently than arbutin does [99]. The effects of calixarbutin on cellular melanogenesis and skin pigmentation are not known. Nonetheless, its cytotoxicity is very strong, and the molecular weight is too big to be used as an anti-melanogenic agent for topical application. Rather, its use for anticancer purposes is expected. 
Table 3. Tyrosinase inhibitory effects of various esters of arbutin.

\begin{tabular}{|c|c|c|c|c|c|}
\hline \multirow{2}{*}{ Literature } & \multicolumn{2}{|c|}{ Compounds } & \multicolumn{2}{|c|}{ Tyrosinase Inhibitory Effects } & \multirow{2}{*}{$\begin{array}{l}\text { Enzymes and } \\
\text { Substrates Used }\end{array}$} \\
\hline & Name & $\begin{array}{l}\text { Chemical } \\
\text { Structure }\end{array}$ & Monophenolase Activity & $\begin{array}{l}\text { Diphenolase } \\
\text { Activity }\end{array}$ & \\
\hline \multirow{2}{*}{ [95] } & \multirow{2}{*}{$\begin{array}{c}\text { Arbutin } \\
\text { Arbutin undecylenic } \\
\text { acid ester }\end{array}$} & 2 & $\mathrm{IC}_{50}=3 \mathrm{mM}$ & $\mathrm{IC}_{50}=40 \mathrm{mM}$ & \multirow{2}{*}{$\begin{array}{c}\text { Mushroom tyrosinase; } \\
1 \mathrm{mM} \text { catechol or } \\
1 \mathrm{mM} \text { phenol }\end{array}$} \\
\hline & & 17 & $\mathrm{IC}_{50}=0.4 \mathrm{mM}$ & $\mathrm{IC}_{50}=0.4 \mathrm{mM}$ & \\
\hline \multirow{2}{*}{ [98] } & Grevilloside M & 19 & & No inhibition & \multirow{2}{*}{$\begin{array}{c}\text { Mushroom tyrosinase; } \\
2.5 \mathrm{mM} \text { L-DOPA }\end{array}$} \\
\hline & Robustaside D & 20 & & No inhibition & \\
\hline \multirow{5}{*}{ [96] } & Arbutin & 2 & $1.72 \%$ inhibition at $0.2 \mathrm{mM}$ & Not detected & \multirow{5}{*}{$\begin{array}{l}\text { Mushroom tyrosinase; } \\
2 \text { mM L-tyrosine or } \\
1 \text { mM L-DOPA }\end{array}$} \\
\hline & Arbutin propionate & 15 & $0.86 \%$ inhibition at $0.2 \mathrm{mM}$ & Not detected & \\
\hline & Arbutin octylate & 16 & $8.42 \%$ inhibition at $0.2 \mathrm{mM}$ & Not detected & \\
\hline & Arbutin undecenoate & 17 & $15.64 \%$ inhibition at $0.2 \mathrm{mM}$ & $\begin{array}{l}8.01 \% \text { inhibition } \\
\text { at } 0.2 \mathrm{mM}\end{array}$ & \\
\hline & Arbutin laurate & 18 & Not detected & Not detected & \\
\hline \multirow{2}{*}{ [97] } & \multirow{2}{*}{$\begin{array}{c}\text { Arbutin } \\
\text { Arbutin undecylenic } \\
\text { acid ester }\end{array}$} & 2 & & $\mathrm{IC}_{50}=29.4 \mathrm{mM}$ & \multirow{2}{*}{$\begin{array}{l}\text { Silkworm hemolymph } \\
\text { polyphenol oxidase; } \\
\text { 14.4 mM L-DOPA }\end{array}$} \\
\hline & & 17 & & $\mathrm{IC}_{50}=6.36 \mathrm{mM}$ & \\
\hline
\end{tabular}

\subsection{Deoxyarbutin}

Deoxyarbutin (Chemical structure 22, Figure 4) was shown to be an effective inhibitor of mushroom TYR in vitro more potent than hydroquinone and arbutin $[100,101]$. In a hairless, pigmented guinea pig model, deoxyarbutin demonstrated rapid and sustained skin lightening whereas hydroquinone induced a transient skin lightening effect, and kojic acid and arbutin exhibited no significant skin lightening effect [100]. In a human clinical trial, topical treatment of $3 \%$ deoxyarbutin for 12 weeks improved solar lentigines in dark skin individuals, although it slightly reduced skin lightness in a population of light skin [100].

Another double-blind randomized controlled study was conducted treating a total of 59 women participants with $2 \%$ deoxyarbutin or $4 \%$ hydroquinone serum for 12 weeks [102]. During this period, the melanin index changed from 246.88 to 199.61 in the deoxyarbutintreated group and from 244.22 to 203.98 in the hydroquinone-treated group, and skin lightness (L value) changed from 52.41 to 54.08 in the deoxyarbutin-treated group, and from 52.58 to 54.08 in the hydroquinone-treated group. Thus, it was concluded that that $2 \%$ deoxyarbutin and $4 \%$ hydroquinone sera showed comparable depigmenting efficacy. Despite these positive clinical results, there is a concern that deoxyarbutin may be degraded to produce hydroquinone, which may cause toxicity (Table 4).

Table 4. Opinion of the scientific committee on consumer safety (SCCS) on the safety of the use of arbutin, $\alpha$-arbutin, and deoxyarbutin in cosmetic products.

\begin{tabular}{|c|c|c|c|}
\hline \multirow{2}{*}{ Literature } & \multicolumn{2}{|c|}{ Compounds } & \multirow{2}{*}{ Statements } \\
\hline & Name & Chemical Structure & \\
\hline$[103]$ & Arbutin & 2 & $\begin{array}{l}\text { "The SCCS considers the use of } \beta \text {-arbutin to } \\
\text { be safe for consumers in cosmetic products in } \\
\text { a concentration up to } 7 \% \text { in face creams } \\
\text { provided that the contamination of } \\
\text { hydroquinone in the cosmetic formulations } \\
\text { remain below } 1 \text { ppm." }\end{array}$ \\
\hline [104] & $\alpha$-arbutin & 3 & $\begin{array}{l}\text { "The SCCS considers the use of } \alpha \text {-arbutin } \\
\text { safe for consumers in cosmetic products in } \\
\text { a concentration up to } 2 \% \text { in face creams and } \\
\text { up to } 0.5 \% \text { in body lotions." }\end{array}$ \\
\hline$[105]$ & Deoxyarbutin & 22 & $\begin{array}{l}\text { "Therefore, the overall conclusion of the } \\
\text { SCCS is that the use of deoxyarbutin } \\
\text { up to } 3 \% \text { in face creams is not safe." }\end{array}$ \\
\hline
\end{tabular}


<smiles>O=C(O)/C=C/c1ccc(O)cc1</smiles>

p-Coumaric acid (르)<smiles>O=c1oc2c(O)c(O)cc3c(=O)oc4c(O)c(O)cc1c4c23</smiles>

Ellagic acid (24)<smiles>O=C1OC(C(O)CO)C(O)=C1O</smiles>

Vitamin C (ascorbic acid, 25)<smiles></smiles>

Aloesin (26)<smiles>CCCCCCCCCCCCC/C=C1\C(=O)OC(=C(C)C)C1O</smiles>

Linderanolide B (므)<smiles>O=c1cc(CO)occ1O</smiles>

Kojic acid (요)<smiles>COc1cc(CNC(=O)CCCC/C=C/C(C)C)ccc1O</smiles>

Capsaicin (29)<smiles>CC1=C(/C=C/C(C)=C/C=C/C(C)=C/C=O)C(C)(C)CCC1</smiles>

Retinaldehyde (르)

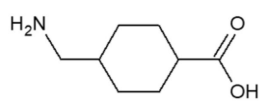

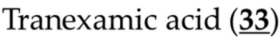

cotinamide (niaciamide, $\underline{\text { 30}}$ )

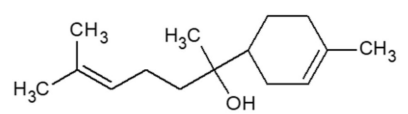

Bisabolol (푸)

Figure 5. Chemical structures of various compounds that can affect the depigmenting activity of arbutin. Most compounds can additively or synergistically enhance the activity of arbutin, whereas capsaicin antagonizes the activity of arbutin.

Liao et al. reported that transdermal delivery of $\alpha$-arbutin could be enhanced by ultrasound-assisted technology [113]. Ultrasound treatment using albumin-shelled microbubbles as a contrast agent improved in vitro penetration of $\alpha$-arbutin through C57BL/6J mouse skin. The microbubble/ultrasound-assisted treatment of $\alpha$-arbutin solution for 4 weeks enhanced skin lightness of mice, more effectively than conventional treatment of $\alpha$-arbutin solution. Aung et al. introduced $\alpha$-arbutin-loaded dissolving microneedles and hydrogel-forming microneedles $[114,115]$. The microneedles showed enhanced intradermal delivery and skin accumulations of $\alpha$-arbutin in vivo in mice compared to commercial $\alpha$-arbutin cream. Kim et al. constructed arbutin-imprinted biomaterials for use in facial mask products [116]. 


\section{Clinical Evaluation of Skin Depigmenting Efficacy}

\subsection{Skin Depigmenting Efficacy of Arbutin}

Choi et al. evaluated the depigmenting efficacy of aloesin and arbutin in a human study [117]. After irradiating the skin area of the forearm with UVR, a 10\% solution of each substance was treated alone or together 4 times daily for 15 days. As a result, aleosin, arbutin, and their co-treatment reduced the UVR-induced hyperpigmentation by $34 \%$, $43.5 \%$, and $63.3 \%$, respectively compared to the vehicle treatment.

A randomized, prospective, open-label study of female patients aged 26-50 years with epidermal or mixed melasma evaluated the skin-lightening effects of arbutin and ellagic acid (Chemical structure 24, Figure 5) [118]. A gel formulation containing arbutin (1\%), ellagic acid $(1 \%)$, or ellagic acid plus plant extract (each $1 \%$ ) was applied to the face twice a day for 6 months, and the skin melanin index was measured before and after using the product. The above three gel formulations reduced the melanin index to $71 \%(p=0.05)$, $79 \%(p=0.38)$ and $76 \%(p<0.05)$ levels of baseline, respectively. No evaluation of control products without an active ingredient was performed and this is a limitation of this study.

A randomized, placebo-controlled, double-blind trial involving 102 women, aged 26-55, with melasma and solar lentigines, evaluated depigmenting efficacy of arbutin derived from Serratulae quinquefoliae [119]. The study group $(n=54)$ applied the cream containing the plant extract (final concentration of arbutin $2.51 \%$ ) twice a day on the discolored side for 8 weeks. The results showed that the cream with the plant extract decreased melanin level in the skin pigmentation spot, compared to the control group $(n=48)$ applied with a placebo cream without the active ingredient. During 8 weeks of application, the melanin level of the test group decreased from $182.60 \pm 39.41$ to $168.76 \pm 36.30(p<0.000001)$, and there was no significant change from $158.9 \pm 34.41$ to $166.84 \pm 39.72$ in the control group. Clinical improvement was observed in $75.86 \%$ of the female patients with melasma and $56.00 \%$ of the female patients with solar lentigines.

\subsection{Combination with Other Active Ingredients}

TYR inhibitory activity of arbutin was shown to be enhanced by combination with L-ascorbic acid (Chemical structure 25, Figure 5), particularly when oxygen is limited [55]. Co-treatment of aloesin (Chemical structure 26, Figure 5) and arbutin was shown to inhibit mushroom TYR activity synergistically [120]. These two compounds also reduced the TYR activity and melanogenesis of cultured human melanocytes synergistically [121]. Synergistic effects inhibiting TYR activity and reducing melanin content of B16F10 cells were also observed between linderanolide B (Chemical structure 27, Figure 5), a natural compound purified from Cinnamomum subavenium, and arbutin or kojic acid (Chemical structure 28, Figure 5) [122]. The inhibitory effect of arbutin on TYR expression and melanin synthesis was reversed by capsaicin (Chemical structure 29, Figure 5) in B16 mouse melanoma cells [123].

There have been several studies evaluating a combination formulation containing arbutin in clinical trials. In a prospective, single-arm, open-label study involving 33 participants with epidermal melasma [124], a cream formulation containing $4 \%$ nicotinamide (niacinamide, Chemical structure 30, Figure 5), 3\% arbutin, 1\% bisabolol (Chemical structure 31, Figure 5), and $0.05 \%$ retinaldehyde (Chemical structure 32, Figure 5) was applied to the entire face once daily for 60 days. There was a mean reduction in MASI (melasma area and severity index) score for 60 days $(2.25 \pm 1.87, p<0.0001)$. The mean total melasma surface was significantly reduced from $1398.5 \mathrm{~mm}^{2}$ at baseline to $923.4 \mathrm{~mm}^{2}$ at day $60(p<0.0001)$.

In a three-arm randomized controlled trial involving a total of 44 subjects [125], treatment of a combination serum that contained $4 \%$ ferment filtrate, $2 \%$ niacinamide, $4 \%$ $\alpha$-arbutin, and $2 \%$ or $3 \%$ tranexamic acid (Chemical structure 33, Figure 5) showed a significant improvement in skin brightness and pigmentation intensity after 4 weeks $(p<0.001)$. There were no differences in skin depigmenting efficacy between the combination serum treatment groups and the $4 \%$ hydroquinone treatment group. 
A prospective, randomized, controlled split-face study [126] evaluated the hyperpigmentation improvement effect of a non-hydroquinone topical formulation (SKNB19) containing epidermal growth factor, tranexamic acid, vitamin $C$, arbutin, niacinamide, and other ingredients and a standard formulation containing $4 \%$ hydroquinone. Eighteen adult subjects with facial pigmentation were randomly assigned to apply SKNB19 twice daily to one side of their face and $4 \%$ hydroquinone at night to the other side. SKNB19treated skin showed a statistically significant improvement in the overall appearance of hyperpigmentation and was rated better than hydroquinone-treated skin.

\subsection{Combination Therapy with a Laser Treatment}

A prospective study of 35 refractory melasma cases treated with 10 weekly laser sessions using a Q-switched Nd:YAG laser (MedLite C6), two monthly follow-up laser sessions, and topical $7 \% \alpha$-arbutin solution supported that the combination therapy is an effective and well-tolerated treatment for refractory melisma [127]. At 6 months, 66.7\% of study subjects showed more than a $51 \%$ reduction of melisma even though mild and transient side effects were observed in several cases.

\section{Antioxidant Properties of Arbutin and $\alpha$-Arbutin}

\subsection{Reactive Oxygen Species in Melanin Synthesis}

Melanin plays an important role in skin protection by absorbing UVR [128], but conversely, its synthetic process including reactions catalyzed by TYR generates reactive oxygen species (ROS) [129]. Independently of this, UVR, pollution, hormones, and drugs can stimulate the generation of ROS in melanocytes [130-133].

ROS of various origins can promote melanogenesis or cause melanocyte death, leading to hyperpigmentation or hypopigmentation [134]. Accumulation of oxidative damage leads to tumorigenesis [135]. Therefore, effective antioxidants are expected to reduce oxidative stress in cells, normalize the process of melanin production, and prevent melanocyte death and tumorigenesis. Oral administration of glutathione attenuated oxidative stress as well as hyperpigmentation $[136,137]$.

\subsection{Nuclear Factor Erythroid 2-Related Factor 2 (Nrf2)-Mediated Pathway}

Cells have various forms of antioxidant defense, including the Nrf2-mediated pathway $[40,138]$. Nrf2 is a transcription factor that binds to antioxidant responsive elements (ARE) on the promoter regions of many phase II metabolism/antioxidant enzymes [139]. Activation of the Nrf2-ARE pathway leads to induction of phase II metabolic/antioxidant enzymes and increase of the low molecular antioxidants, such as glutathione [140].

Nrf2 was shown to negatively regulate melanin synthesis in cells through modulation of phosphoinositide 3-kinase/protein kinase B signaling pathway [141]. Dietary phenolics could suppress UVR-induced melanogenesis through stimulation of the Nrf2-ARE pathway in addition to their antioxidant and UVR absorption properties [142].

\subsection{Antioxidant Properties of Arbutin and $\alpha$-Arbutin}

Takebayashi et al. examined the antioxidant activity of arbutin compared to that of hydroquinone [143]. Arbutin was a weaker scavenger against 1,1-diphenyl-2-picrylhydrazyl radical and a more potent scavenger against 2,2'-azinobis (3-ethylbenzothiazoline-6-sulphonic acid) cation radical compared to hydroquinone. Arbutin exerted slower but long-lasting scavenging activity against 2,2'-azobis (2-methylpropionamidine) dihydrochloride (AAPH)-derived peroxyl radical compared to hydroquinone. At $50 \mu \mathrm{M}$ arbutin prevented AAPH-induced hemolysis of erythrocytes more effectively than hydroquinone. Arbutin $(125-1000 \mu \mathrm{M})$ rescued skin fibroblasts exposed to AAPH, whereas hydroquinone $(125 \mu \mathrm{M})$ exerted cytotoxicity.

Tada et al. detected hydroxyl radical generation from the TYR-catalyzed oxidations of L-tyrosine and L-DOPA, using an electron spin resonance-spin trapping technique [144]. They also observed that arbutin attenuated the hydroxyl radical generation in both reactions, suggesting that arbutin can reduce the levels of ROS derived from the melanogenic 
pathway. Arbutin at $500 \mu \mathrm{M}$ was also shown to reduce intracellular hydroxyl radical production and prevent mitochondrial membrane potential loss and played an anti-apoptotic role in human lymphoma U937 cells irradiated with X-ray [145]. Arbutin attenuated the tert-butyl hydroperoxide-induced oxidative stress in human liver cancer HepG2 cell line (effective concentration, $150 \mu \mathrm{M}$ ) [146], human prostate cancer LNCaP cell line, and human fibroblasts (250 and $1000 \mu \mathrm{M})$ [147].

Polouliakh et al. conducted in silico comparative genomics analysis in human dermal fibroblasts treated with $\alpha$-arbutin, and identified transcription factors with a potential role in tumor suppression, toxicity response, and wound healing [148]. $\alpha$-arbutin upregulated Nrf2 transcription factor which consequently activates target genes involved in antioxidant defense. Arbutin attenuated lipopolysaccharide-induced acute kidney injury in rats, by inhibiting inflammation and apoptosis via the phosphoinositide 3-kinase/protein kinase B/Nrf2 pathway [149]. Arbutin also decreased the levels of pro-inflammatory cytokines and enhanced myocardial antioxidant status, attenuating isoproterenol-induced cardiac hypertrophy in mice [150].

Thus, arbutin and $\alpha$-arbutin may reduce ROS levels by directly scavenging free radicals or indirectly enhancing the antioxidant capacity of cells through the activation of the Nrf2-ARE pathway. These antioxidant properties may contribute to the inhibitory action of arbutin and $\alpha$-arbutin on melanin synthesis in cells.

\section{Discussion}

The generally agreed view on the mechanism by which arbutin inhibits the melanin synthesis in cells is that it inhibits the catalytic activity of already expressed TYR or irreversibly inactivates it rather than suppressing the new synthesis of TYR. Many studies reported that arbutin did not affect mRNA and protein expression of TYR in the concentration range where it inhibited cellular melanin synthesis. There are only a few reports that arbutin reduced the protein level of intracellular TYR [123].

Arbutin is structurally similar to L-tyrosine and can bind to the active site of TYR, thereby acting as a competitive inhibitor. In addition, arbutin can irreversibly inactivate TYR by binding to the enzyme in the form of $E_{m e t}$ when diphenol substrates are deficient. Of course, there is a possibility that arbutin may act as a substrate for TYR in the form of $E_{\text {oxy }}$ when diphenol substrates are present. The last mechanism may not be excluded, because arbutin has been shown to increase cellular melanin synthesis at certain conditions [61]. However, most studies support the mechanism by which arbutin inhibits the catalytic activity of TYR or causes its irreversible inactivation, thereby preventing the synthesis of melanin in cells.

Arbutin exhibits different levels of toxicity depending on the cell type and exposure time, but $1 \mathrm{mM}$ is considered as a boundary concentration between cytotoxicity and safety (Table 5). Therefore, the alleviating action of arbutin on cellular melanin synthesis and oxidative stress observed at a concentration of $1 \mathrm{mM}$ or lower is interpreted as physiologically significant. When arbutin is treated in vivo, its concentration in contact with cells must be maintained at $1 \mathrm{mM}$ or lower, so that beneficial efficacy without the risk of serious side effects can be expected.

Studies on the antioxidant activity of arbutin are emerging [143,147]. Arbutin scavenges ROS, such as hydroxyl radicals [144], and activates the Nrf2-ARE pathway enhancing the antioxidant capacity of cells [149]. Arbutin can inhibit ROS-mediated signal transduction in melanocytes and prevent skin hyperpigmentation, like other dietary phenolic compounds [142]. In addition, the increased pool of intracellular thiol compounds may enhance pheomelanin synthesis and reduce eumelanin synthesis through the formation of DOPA-thiol conjugates $[45,136,137]$. The antioxidant action-based mechanism and the mechanism based on the TYR inhibitory action are not mutually exclusive and are assumed to work together for the inhibition of eumelanin synthesis (Figure 6). 
Table 5. Effects of arbutin on the viability of different cells.

\begin{tabular}{|c|c|c|}
\hline Literature & Cells & Effects of Arbutin on Cell Viability \\
\hline$[50,52]$ & $\begin{array}{c}\text { Human melanocytes derived from neonatal } \\
\text { Caucasian } \\
\text { or Asian neonatal foreskins }\end{array}$ & $\begin{array}{c}\text { Arbutin treatment at } 0.01-1.0 \mathrm{mM} \text { for } 3 \mathrm{~d} \text { did not reduce cell } \\
\text { viability whereas } 5 \mathrm{mM} \text { treatment } \\
\text { reduced cell viability by } 26 \% .\end{array}$ \\
\hline [53] & $\begin{array}{l}\text { Normal human melanocytes from foreskins of } \\
\text { 18- to 40-year-old Japanese males }\end{array}$ & $\begin{array}{c}\text { Cells grew well in the presence of } 0.37 \mathrm{mM} \text { arbutin for } 5 \mathrm{~d} \text {, } \\
\text { but } 1.1 \mathrm{mM} \text { arbutin was cytotoxic and } \\
\text { cells detached from the dish within } 48 \mathrm{~h} .\end{array}$ \\
\hline$[56]$ & $\begin{array}{l}\text { BRUCE-4 embryonic stem cells of C57BL/6J mouse; } \\
\text { Mouse bone marrow-derived stromal ST2 cells }\end{array}$ & $\begin{array}{l}\text { Arbutin treatment for } 24 \mathrm{~h} \text { did not inhibit } \\
\text { the proliferation of either cell at } 1 \mathrm{mM} \text {. }\end{array}$ \\
\hline [94] & Murine melanoma B16 cells & $\begin{array}{l}\text { After } 24 \mathrm{~h} \text { of treatment, up to } 3.6 \mathrm{mM} \text { arbutin } \\
\text { had no significant effect on cell viability. } \\
\text { After } 48 \mathrm{~h} \text {, up to } 0.7 \mathrm{mM} \text { arbutin did not } \\
\text { induce significant toxicity. } \\
\text { After } 72 \mathrm{~h}, 0.3-5.4 \mathrm{mM} \text { arbutin reduced cell viability } \\
\text { by } 24-45 \% \text {. Arbutin at } 5.4 \mathrm{mM} \text { induced apoptosis. }\end{array}$ \\
\hline [143] & Normal human skin fibroblasts & $\begin{array}{l}\text { Treatment with up to } 1 \mathrm{mM} \text { arbutin for } 24 \mathrm{~h} \\
\text { did not affect cell viability. }\end{array}$ \\
\hline [151] & $\begin{array}{c}\text { Human prostate carcinoma. The LNCaP cell line } \\
\text { Human prostate carcinoma LNCaP cells }\end{array}$ & $\begin{array}{c}\text { Treatment with } 125-2000 \mu \mathrm{M} \text { for } 24,48 \text {, or } 72 \mathrm{~h} \\
\text { did not significantly affect cell viability.Arbutin induced } \\
\text { apoptosis at } 1000 \mu \mathrm{M} \text {. }\end{array}$ \\
\hline [147] & $\begin{array}{l}\text { Fibroblast cell line from human newborn foreskins; } \\
\text { LNCaP cells }\end{array}$ & $\begin{array}{l}\text { Arbutin reduced the viability of these cells } \\
\text { at doses above } 1000 \mu \mathrm{M} \text { at } 24 \text { and } 48 \mathrm{~h} \text { post-exposure. }\end{array}$ \\
\hline
\end{tabular}

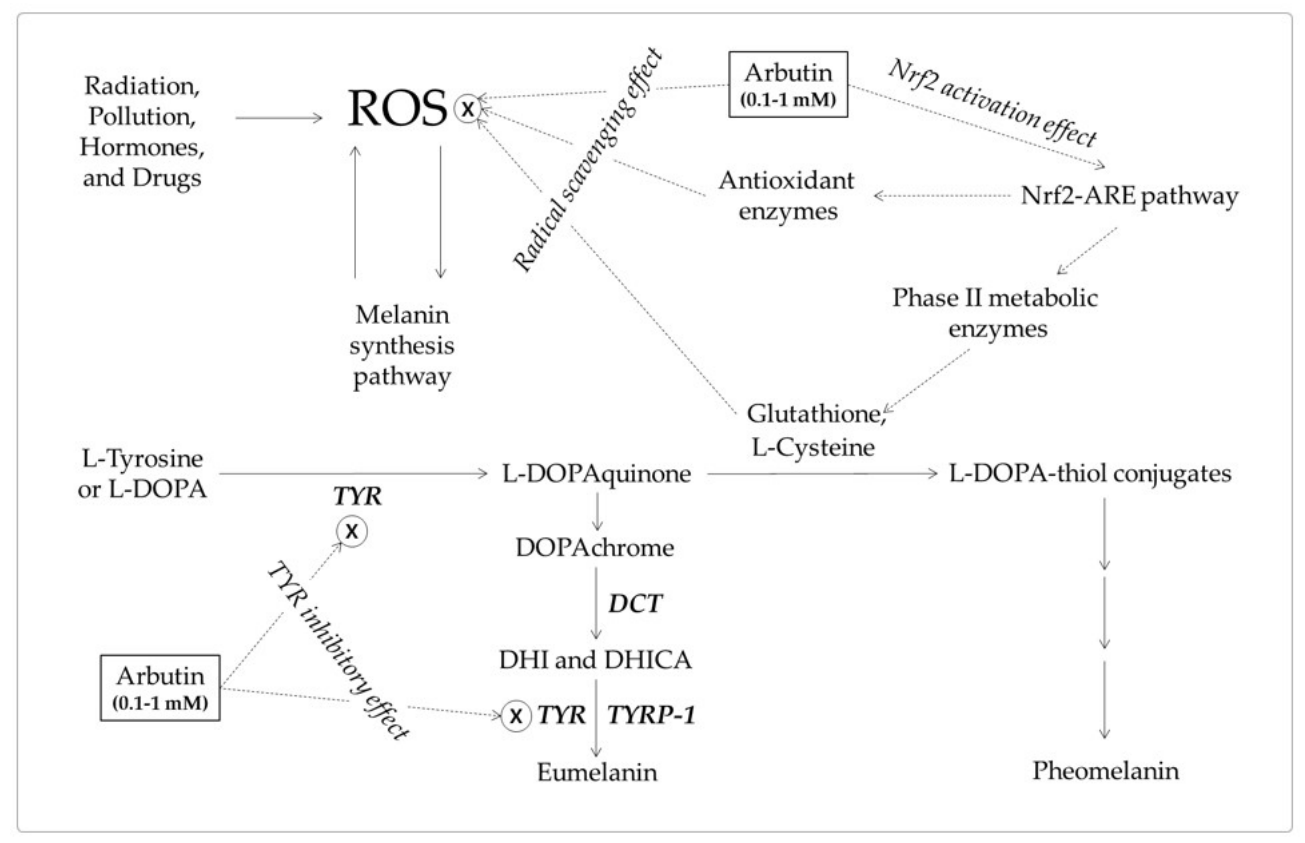

Figure 6. A hypothetical mechanism for the inhibition of eumelanin synthesis by arbutin involving its tyrosinase (TYR) inhibitory and antioxidant activities. Arbutin inhibits the catalytic activity of TYR. It also scavenges reactive oxygen species (ROS) from various sources that can induce melanin synthesis, apoptosis, or tumorigenesis. It can activate the erythroid 2-associated factor 2 (Nrf2)-antioxidant responsive elements (ARE) pathway to enhance the antioxidant capacity of cells. Increased thiol compounds, such as L-cysteine and glutathione, can react with L-DOPAquinon to form DOPA-thiol conjugates, which enter the pheomelanin synthesis pathway. As a result, eumelanin synthesis via DOPAchrome can be selectively downregulated by arbutin. Inhibitory targets of arbutin are indicated with $\otimes$. 
There is still no consensus as to which arbutin or $\alpha$-arbutin is better in terms of TYR inhibition, cell melanin synthesis inhibition, and skin lightening efficacy and safety. In addition, whether they inhibit cell melanin synthesis or show skin lightening action through the production of hydroquinone has not been completely resolved. Despite these controversies, the results of animal tests and clinical trials prove that arbutin and $\alpha$-arbutin have the effect of alleviating skin pigmentation.

Arbutin and $\alpha$-arbutin have the possibility to produce hydroquinone in the manufacturing process of raw materials, the manufacturing and storage process of cosmetic products, and the human use of the products. Whether they are chemically synthesized, extracted from plants, or produced by biological conversion processes, it is an important goal to achieve high purity in the final raw materials. The formulation is important to stabilize arbutin or $\alpha$-arbutin in the final products. It should be remembered that exposure to microorganisms or UVR during storage and use of the product has the potential to generate hydroquinone $[59,60]$. Since dermatitis or allergic dermatitis has been observed in certain people using arbutin-containing cosmetic products $[152,153]$, if any side effects are observed while using the product, one must discontinue use immediately and consult a doctor.

Substances and therapies that can synergize with arbutin are attracting attention $[117,120,122]$. Rather than using arbutin alone, a strategy for maximizing the skin lightening efficacy by combining it with other active ingredients with different mechanisms of action is preferred [124-126]. In future studies, it is hoped that more diverse active ingredients can be combined so that a highly synergistic increase in efficacy can be achieved. Techniques that aid in the transdermal absorption and efficient release of active ingredients are also needed. Nanoemulsions [110], nanoparticles [111,112], and microneedles [114] containing arbutin have been developed. Ultrasonic treatment with microbubbles is could promote percutaneous absorption [113]. Of course, a comprehensive treatment strategy that combines pharmacological treatment with laser treatment is expected to give added benefits [127].

\section{Conclusions}

In conclusion, the position of arbutin as a skin depigmenting agent is somewhere between the advantages of efficacy and the disadvantages of side effects. Therefore, knowledge of how cosmetic products containing arbutin are made, managed, and used is important. A hypothetical model for the depigmenting mechanism of arbutin involving antioxidant action as well as TYR inhibition is proposed. It is expected that more advanced depigmenting products will be developed based on accumulated information on arbutin and related substances. It is also expected that future research will examine whether arbutin can be applied to skin disorders other than hyperpigmentation.

Funding: This research was supported by a grant of the Korea Health Technology R\&D Project through the Korea Health Industry Development Institute (KHIDI), funded by the Ministry of Health and Welfare, Republic of Korea (grant number: HP20C0004).

Conflicts of Interest: The authors declare no conflict of interest.

\section{References}

1. Saade, D.S.; Maymone, M.B.C.; De La Garza, H.; Secemsky, E.A.; Kennedy, K.F.; Vashi, N.A. Trends in Use of Prescription Skin Lightening Creams. Int. J. Environ. Res. Public Health 2021, 18, 5650. [CrossRef] [PubMed]

2. Neagu, N.; Conforti, C.; Agozzino, M.; Marangi, G.F.; Morariu, S.H.; Pellacani, G.; Persichetti, P.; Piccolo, D.; Segreto, F.; Zalaudek, I.; et al. Melasma treatment: A systematic review. J. Dermatolog. Treat. 2021, 1-39. [CrossRef] [PubMed]

3. Jow, T.; Hantash, B.M. Hydroquinone-induced depigmentation: Case report and review of the literature. Dermatitis 2014, 25, e1-e5. [CrossRef]

4. Ozbey, R.; Okur, M.I. The use of $4 \%$ hydroquinone, $0.1 \%$ tretinoin, and $0.1 \%$ betamethasone creams to prevent hyperpigmentation of split-thickness skin grafts in Long-Evans rats. J. Cosmet. Dermatol. 2020, 19, 2663-2668. [CrossRef]

5. Jimbow, K.; Obata, H.; Pathak, M.A.; Fitzpatrick, T.B. Mechanism of depigmentation by hydroquinone. J. Investig. Dermatol. 1974, 62, 436-449. [CrossRef]

6. Kooyers, T.J.; Westerhof, W. Toxicology and health risks of hydroquinone in skin lightening formulations. J. Eur. Acad. Dermatol. Venereol. 2006, 20, 777-780. [CrossRef] 
7. Draelos, Z.D. Skin lightening preparations and the hydroquinone controversy. Dermatol. Ther. 2007, 20, 308-313. [CrossRef]

8. Xu, W.H.; Liang, Q.; Zhang, Y.J.; Zhao, P. Naturally occurring arbutin derivatives and their bioactivities. Chem. Biodivers. 2015, 12, 54-81. [CrossRef]

9. Saeedi, M.; Khezri, K.; Seyed Zakaryaei, A.; Mohammadamini, H. A comprehensive review of the therapeutic potential of alpha-arbutin. Phytother. Res. 2021. [CrossRef]

10. Akiu, S.; Suzuki, Y.; Asahara, T.; Fujinuma, Y.; Fukuda, M. Inhibitory effect of arbutin on melanogenesis-biochemical study using cultured B16 melanoma cells. Nippon Hifuka Gakkai Zasshi 1991, 101, 609-613. [PubMed]

11. Slominski, A.; Kim, T.K.; Brozyna, A.A.; Janjetovic, Z.; Brooks, D.L.; Schwab, L.P.; Skobowiat, C.; Jozwicki, W.; Seagroves, T.N. The role of melanogenesis in regulation of melanoma behavior: Melanogenesis leads to stimulation of HIF-1alpha expression and HIF-dependent attendant pathways. Arch. Biochem. Biophys. 2014, 563, 79-93. [CrossRef]

12. Slominski, R.M.; Zmijewski, M.A.; Slominski, A.T. The role of melanin pigment in melanoma. Exp. Dermatol. 2015, 24, 258-259. [CrossRef]

13. Yamaguchi, Y.; Beer, J.Z.; Hearing, V.J. Melanin mediated apoptosis of epidermal cells damaged by ultraviolet radiation: Factors influencing the incidence of skin cancer. Arch. Dermatol. Res. 2008, 300 (Suppl. 1), S43-S50. [CrossRef]

14. Boo, Y.C. Emerging Strategies to Protect the Skin from Ultraviolet Rays Using Plant-Derived Materials. Antioxidants 2020, 9 , 637. [CrossRef]

15. Rose, P.T. Pigmentary disorders. Med. Clin. N. Am. 2009, 93, 1225-1239. [CrossRef]

16. Ganju, P.; Nagpal, S.; Mohammed, M.H.; Nishal Kumar, P.; Pandey, R.; Natarajan, V.T.; Mande, S.S.; Gokhale, R.S. Microbial community profiling shows dysbiosis in the lesional skin of Vitiligo subjects. Sci. Rep. 2016, 6, 18761. [CrossRef]

17. Spritz, R.A.; Andersen, G.H. Genetics of Vitiligo. Dermatol. Clin. 2017, 35, 245-255. [CrossRef] [PubMed]

18. Costin, G.E.; Hearing, V.J. Human skin pigmentation: Melanocytes modulate skin color in response to stress. FASEB J. 2007, 21, 976-994. [CrossRef] [PubMed]

19. Slominski, A.T.; Zmijewski, M.A.; Skobowiat, C.; Zbytek, B.; Slominski, R.M.; Steketee, J.D. Sensing the environment: Regulation of local and global homeostasis by the skin's neuroendocrine system. Adv. Anat. Embryol. Cell Biol. 2012, $212,1-115$.

20. Iwata, M.; Corn, T.; Iwata, S.; Everett, M.A.; Fuller, B.B. The relationship between tyrosinase activity and skin color in human foreskins. J. Investig. Dermatol. 1990, 95, 9-15. [CrossRef] [PubMed]

21. Iozumi, K.; Hoganson, G.E.; Pennella, R.; Everett, M.A.; Fuller, B.B. Role of tyrosinase as the determinant of pigmentation in cultured human melanocytes. J. Investig. Dermatol. 1993, 100, 806-811. [CrossRef]

22. Slominski, A.; Tobin, D.J.; Shibahara, S.; Wortsman, J. Melanin pigmentation in mammalian skin and its hormonal regulation. Physiol. Rev. 2004, 84, 1155-1228. [CrossRef]

23. Videira, I.F.; Moura, D.F.; Magina, S. Mechanisms regulating melanogenesis. An. Bras. Dermatol. 2013, 88, 76-83. [CrossRef] [PubMed]

24. Steinhoff, M.; Stander, S.; Seeliger, S.; Ansel, J.C.; Schmelz, M.; Luger, T. Modern aspects of cutaneous neurogenic inflammation. Arch. Dermatol. 2003, 139, 1479-1488. [CrossRef] [PubMed]

25. Yasumoto, K.; Yokoyama, K.; Takahashi, K.; Tomita, Y.; Shibahara, S. Functional analysis of microphthalmia-associated transcription factor in pigment cell-specific transcription of the human tyrosinase family genes. J. Biol. Chem. 1997, 272, 503-509. [CrossRef] [PubMed]

26. Busca, R.; Ballotti, R. Cyclic AMP a key messenger in the regulation of skin pigmentation. Pigment Cell Res. 2000, 13, 60-69. [CrossRef] [PubMed]

27. Flaherty, K.T.; Hodi, F.S.; Fisher, D.E. From genes to drugs: Targeted strategies for melanoma. Nat. Rev. Cancer 2012, 12, 349-361. [CrossRef] [PubMed]

28. Serre, C.; Busuttil, V.; Botto, J.M. Intrinsic and extrinsic regulation of human skin melanogenesis and pigmentation. Int. J. Cosmet. Sci. 2018, 40, 328-347. [CrossRef] [PubMed]

29. Rzepka, Z.; Buszman, E.; Beberok, A.; Wrzesniok, D. From tyrosine to melanin: Signaling pathways and factors regulating melanogenesis. Postepy Hig. Med. Dosw. 2016, 70, 695-708. [CrossRef] [PubMed]

30. D’Mello, S.A.; Finlay, G.J.; Baguley, B.C.; Askarian-Amiri, M.E. Signaling Pathways in Melanogenesis. Int. J. Mol. Sci. 2016, 17, 1144. [CrossRef]

31. Yuan, X.H.; Jin, Z.H. Paracrine regulation of melanogenesis. Br. J. Dermatol. 2018, 178, 632-639. [CrossRef]

32. Cooksey, C.J.; Garratt, P.J.; Land, E.J.; Pavel, S.; Ramsden, C.A.; Riley, P.A.; Smit, N.P. Evidence of the indirect formation of the catecholic intermediate substrate responsible for the autoactivation kinetics of tyrosinase. J. Biol. Chem. 1997, 272, 26226-26235. [CrossRef] [PubMed]

33. Simon, J.D.; Peles, D.; Wakamatsu, K.; Ito, S. Current challenges in understanding melanogenesis: Bridging chemistry, biological control, morphology, and function. Pigment Cell Melanoma Res. 2009, 22, 563-579. [CrossRef] [PubMed]

34. Olivares, C.; Solano, F. New insights into the active site structure and catalytic mechanism of tyrosinase and its related proteins. Pigment Cell Melanoma Res. 2009, 22, 750-760. [CrossRef] [PubMed]

35. Longo, D.L.; Stefania, R.; Aime, S.; Oraevsky, A. Melanin-Based Contrast Agents for Biomedical Optoacoustic Imaging and Theranostic Applications. Int. J. Mol. Sci. 2017, 18, 1719. [CrossRef] [PubMed]

36. Davy, A.D.; Birch, D.J.S. Evidence for pheomelanin sheet structure. Appl. Phys. Lett. 2018, 113, 263701. [CrossRef]

37. Grieco, C.; Kohl, F.R.; Hanes, A.T.; Kohler, B. Probing the heterogeneous structure of eumelanin using ultrafast vibrational fingerprinting. Nat. Commun. 2020, 11, 4569. [CrossRef] 
38. Ando, H.; Kondoh, H.; Ichihashi, M.; Hearing, V.J. Approaches to identify inhibitors of melanin biosynthesis via the quality control of tyrosinase. J. Investig. Dermatol. 2007, 127, 751-761. [CrossRef]

39. Pillaiyar, T.; Manickam, M.; Namasivayam, V. Skin whitening agents: Medicinal chemistry perspective of tyrosinase inhibitors. J. Enzyme Inhib. Med. Chem. 2017, 32, 403-425. [CrossRef]

40. Boo, Y.C. Natural Nrf2 Modulators for Skin Protection. Antioxidants 2020, 9, 812. [CrossRef]

41. Niu, C.; Aisa, H.A. Upregulation of Melanogenesis and Tyrosinase Activity: Potential Agents for Vitiligo. Molecules 2017, 22, 1303. [CrossRef]

42. Pillaiyar, T.; Namasivayam, V.; Manickam, M.; Jung, S.H. Inhibitors of Melanogenesis: An Updated Review. J. Med. Chem. 2018, 61, 7395-7418. [CrossRef]

43. Zolghadri, S.; Bahrami, A.; Hassan Khan, M.T.; Munoz-Munoz, J.; Garcia-Molina, F.; Garcia-Canovas, F.; Saboury, A.A. A comprehensive review on tyrosinase inhibitors. J. Enzyme Inhib. Med. Chem. 2019, 34, 279-309. [CrossRef]

44. Kolbe, L.; Mann, T.; Gerwat, W.; Batzer, J.; Ahlheit, S.; Scherner, C.; Wenck, H.; Stab, F. 4-n-butylresorcinol, a highly effective tyrosinase inhibitor for the topical treatment of hyperpigmentation. J. Eur. Acad. Dermatol. Venereol. 2013, 27 (Suppl. S1), 19-23. [CrossRef]

45. Watanabe, F.; Hashizume, E.; Chan, G.P.; Kamimura, A. Skin-whitening and skin-condition-improving effects of topical oxidized glutathione: A double-blind and placebo-controlled clinical trial in healthy women. Clin. Cosmet. Investig. Dermatol. 2014, 7, 267-274. [CrossRef]

46. Boo, Y.C. p-Coumaric Acid as An Active Ingredient in Cosmetics: A Review Focusing on its Antimelanogenic Effects. Antioxidants 2019, 8, 275. [CrossRef] [PubMed]

47. Boo, Y.C. Human Skin Lightening Efficacy of Resveratrol and Its Analogs: From in Vitro Studies to Cosmetic Applications. Antioxidants 2019, 8, 332. [CrossRef] [PubMed]

48. Boo, Y.C.; Jo, D.J.; Oh, C.M.; Lee, S.Y.; Kim, Y.M. The First Human Clinical Trial on the Skin Depigmentation Efficacy of Glycinamide Hydrochloride. Biomedicines 2020, 8, 257. [CrossRef]

49. Hu, Z.M.; Zhou, Q.; Lei, T.C.; Ding, S.F.; Xu, S.Z. Effects of hydroquinone and its glucoside derivatives on melanogenesis and antioxidation: Biosafety as skin whitening agents. J. Dermatol. Sci. 2009, 55, 179-184. [CrossRef]

50. Maeda, K.; Fukuda, M. In vitro effectiveness of several whitening cosmetic components in human melanocytes. J. Soc. Cosmet. Chem. 1991, 42, 361-368.

51. Lim, Y.J.; Lee, E.H.; Kang, T.H.; Ha, S.K.; Oh, M.S.; Kim, S.M.; Yoon, T.J.; Kang, C.; Park, J.H.; Kim, S.Y. Inhibitory effects of arbutin on melanin biosynthesis of alpha-melanocyte stimulating hormone-induced hyperpigmentation in cultured brownish guinea pig skin tissues. Arch. Pharm. Res. 2009, 32, 367-373. [CrossRef]

52. Maeda, K.; Fukuda, M. Arbutin: Mechanism of its depigmenting action in human melanocyte culture. J. Pharmacol. Exp. Ther. 1996, 276, 765-769. [PubMed]

53. Chakraborty, A.K.; Funasaka, Y.; Komoto, M.; Ichihashi, M. Effect of arbutin on melanogenic proteins in human melanocytes. Pigment Cell Res. 1998, 11, 206-212. [CrossRef] [PubMed]

54. Nihei, K.; Kubo, I. Identification of oxidation product of arbutin in mushroom tyrosinase assay system. Bioorg. Med. Chem. Lett. 2003, 13, 2409-2412. [CrossRef]

55. Hori, I.; Nihei, K.; Kubo, I. Structural criteria for depigmenting mechanism of arbutin. Phytother. Res. 2004, 18, 475-479. [CrossRef] [PubMed]

56. Inoue, Y.; Hasegawa, S.; Yamada, T.; Date, Y.; Mizutani, H.; Nakata, S.; Matsunaga, K.; Akamatsu, H. Analysis of the effects of hydroquinone and arbutin on the differentiation of melanocytes. Biol. Pharm. Bull. 2013, 36, 1722-1730. [CrossRef]

57. Jeon, J.S.; Kim, B.H.; Lee, S.H.; Kwon, H.J.; Bae, H.J.; Kim, S.K.; Park, J.A.; Shim, J.H.; Abd El-Aty, A.M.; Shin, H.C. Simultaneous determination of arbutin and its decomposed product hydroquinone in whitening creams using high-performance liquid chromatography with photodiode array detection: Effect of temperature and $\mathrm{pH}$ on decomposition. Int. J. Cosmet. Sci. 2015, 37, 567-573. [CrossRef]

58. Avonto, C.; Wang, Y.H.; Avula, B.; Wang, M.; Rua, D.; Khan, I.A. Comparative studies on the chemical and enzymatic stability of alpha- and beta-arbutin. Int. J. Cosmet. Sci. 2016, 38, 187-193. [CrossRef]

59. Bang, S.H.; Han, S.J.; Kim, D.H. Hydrolysis of arbutin to hydroquinone by human skin bacteria and its effect on antioxidant activity. J. Cosmet. Dermatol. 2008, 7, 189-193. [CrossRef]

60. Chang, N.F.; Chen, Y.S.; Lin, Y.J.; Tai, T.H.; Chen, A.N.; Huang, C.H.; Lin, C.C. Study of Hydroquinone Mediated Cytotoxicity and Hypopigmentation Effects from UVB-Irradiated Arbutin and DeoxyArbutin. Int. J. Mol. Sci. 2017, 18, 969. [CrossRef]

61. Nakajima, M.; Shinoda, I.; Fukuwatari, Y.; Hayasawa, H. Arbutin increases the pigmentation of cultured human melanocytes through mechanisms other than the induction of tyrosinase activity. Pigment Cell Res. 1998, 11, 12-17. [CrossRef]

62. Rok, J.; Otręba, M.; Buszman, E.; Wrześniok, D. Melanin-From melanocyte to keratinocyte, that is how melanin is transported within the skin. Ann. Acad. Med. Sil. 2012, 66, 60-66.

63. Wu, X.F.; Hammer, J.A. Melanosome transfer: It is best to give and receive. Curr. Opin. Cell Biol. 2014, 29, 1-7. [CrossRef] [PubMed]

64. Zhu, X.; Tian, Y.; Zhang, W.; Zhang, T.; Guang, C.; Mu, W. Recent progress on biological production of alpha-arbutin. Appl. Microbiol. Biotechnol. 2018, 102, 8145-8152. [CrossRef] [PubMed]

65. Zhou, H.; Zhao, J.; Li, A.; Reetz, M.T. Chemical and Biocatalytic Routes to Arbutin (dagger). Molecules 2019, 24, 3303. [CrossRef] [PubMed] 
66. Cui, T.; Nakamura, K.; Ma, L.; Li, J.Z.; Kayahara, H. Analyses of arbutin and chlorogenic acid, the major phenolic constituents in oriental pear. J. Agric. Food Chem. 2005, 53, 3882-3887. [CrossRef]

67. Tumova, L.; Doleckova, I.; Hendrychova, H.; Kasparova, M. Arbutin Content and Tyrosinase Activity of Bergenia Extracts. Nat. Prod. Commun. 2017, 12, 549-552.

68. Cho, J.-Y.; Park, K.Y.; Lee, K.H.; Lee, H.J.; Lee, S.-H.; Cho, J.A.; Kim, W.-S.; Shin, S.-C.; Park, K.-H.; Moon, J.-H. Recovery of arbutin in high purity from fruit peels of pear (Pyrus pyrifolia Nakai). Food Sci. Biotechnol. 2011, 20, 801-807. [CrossRef]

69. Sasaki, C.; Ichitani, M.; Kunimoto, K.K.; Asada, C.; Nakamura, Y. Extraction of arbutin and its comparative content in branches, leaves, stems, and fruits of Japanese pear Pyrus pyrifolia cv. Kousui. Biosci. Biotechnol. Biochem. 2014, 78, 874-877. [CrossRef]

70. Lee, B.-D.; Eun, J.-B. Optimum extraction conditions for arbutin from Asian pear peel by supercritical fluid extraction (SFE) using Box-Behnken design. J. Med. Plants Res. 2012, 6, 2348-2364.

71. Jin, Y.H.; Jeon, A.R.; Mah, J.H. Tyrosinase Inhibitory Activity of Soybeans Fermented with Bacillus subtilis Capable of Producing a Phenolic Glycoside, Arbutin. Antioxidants 2020, 9, 1301. [CrossRef]

72. Shang, Y.Z.; Wei, W.P.; Zhang, P.; Ye, B.C. Engineering Yarrowia lipolytica for Enhanced Production of Arbutin. J. Agric. Food Chem. 2020, 68, 1364-1372. [CrossRef]

73. Kitao, S.; Sekine, H. alpha-D-Glucosyl Transfer to Phenolic Compounds by Sucrose Phosphorylase from Leuconostoc mesenteroides and Production of alpha-Arbutin. Biosci. Biotechnol. Biochem. 1994, 58, 38-42. [CrossRef]

74. Nishimura, T.; Kometani, T.; Takii, H.; Terada, Y.; Okada, S. Purification and Some Properties of Alpha-Amylase from BacillusSubtilis X-23 That Glucosylates Phenolic-Compounds Such as Hydroquinone. J. Ferment. Bioeng. 1994, 78, 31-36. [CrossRef]

75. Zhou, X.; Zheng, Y.T.; Wei, X.M.; Yang, K.D.; Yang, X.K.; Wang, Y.T.; Xu, L.M.; Du, L.Q.; Huang, R.B. Sucrose Isomerase and Its Mutants from Erwinia rhapontici Can Synthesise alpha-Arbutin. Protein Pept. Lett. 2011, 18, 1028-1034. [CrossRef]

76. Seo, D.H.; Jung, J.H.; Ha, S.J.; Cho, H.K.; Jung, D.H.; Kim, T.J.; Baek, N.I.; Yoo, S.H.; Park, C.S. High-yield enzymatic bioconversion of hydroquinone to alpha-arbutin, a powerful skin lightening agent, by amylosucrase. Appl. Microbiol. Biotechnol. 2012, 94, 1189-1197. [CrossRef] [PubMed]

77. Yu, S.H.; Wang, Y.C.; Tian, Y.Q.; Xu, W.; Bai, Y.X.; Zhang, T.; Mu, W.M. Highly efficient biosynthesis of alpha-arbutin from hydroquinone by an amylosucrase from Cellulomonas carboniz. Process Biochem. 2018, 68, 93-99. [CrossRef]

78. Mathew, S.; Adlercreutz, P. Regioselective glycosylation of hydroquinone to alpha-arbutin by cyclodextrin glucanotransferase from Thermoanaerobacter sp. Biochem. Eng. J. 2013, 79, 187-193. [CrossRef]

79. Kurosu, J.; Sato, T.; Yoshida, K.; Tsugane, T.; Shimura, S.; Kirimura, K.; Kino, K.; Usami, S. Enzymatic synthesis of alpha-arbutin by alpha-anomer-selective-glucosylation of hydroquinone using lyophilized cells of Xanthomonas campestris WU. J. Biosci. Bioeng. 2002, 93, 328-330. [CrossRef]

80. Liu, C.; Zhang, P.; Liu, L.; Xu, T.; Tan, T.; Wang, F.; Deng, L. Isolation of alpha-arbutin from Xanthomonas CGMCC 1243 fermentation broth by macroporous resin adsorption chromatography. J. Chromatogr. B Analyt. Technol. Biomed. Life Sci. 2013, 925, 104-109. [CrossRef] [PubMed]

81. Wei, M.; Ren, Y.; Liu, C.; Liu, R.; Zhang, P.; Wei, Y.; Xu, T.; Wang, F.; Tan, T.; Liu, C. Fermentation scale up for alpha-arbutin production by Xanthomonas BT-112. J. Biotechnol. 2016, 233, 1-5. [CrossRef]

82. Wu, P.H.; Nair, G.R.; Chu, I.M.; Wu, W.T. High cell density cultivation of Escherichia coli with surface anchored transglucosidase for use as whole-cell biocatalyst for alpha-arbutin synthesis. J. Ind. Microbiol. Biotechnol. 2008, 35, 95-101. [CrossRef] [PubMed]

83. Wang, Z.X.; Shi, X.X.; Chen, G.R.; Ren, Z.H.; Luo, L.; Yan, J. A new synthesis of alpha-arbutin via Lewis acid catalyzed selective glycosylation of tetra-O-benzyl-alpha-D-glucopyranosyl trichloroacetimidate with hydroquinone. Carbohydr. Res. 2006, 341, 1945-1947. [CrossRef] [PubMed]

84. Cepanec, I.; Litvic, M. Simple and efficient synthesis of arbutin. Arkivoc 2008, 2, 19-24.

85. Funayama, M.; Arakawa, H.; Yamamoto, R.; Nishino, T.; Shin, T.; Murao, S. Effects of alpha- and beta-arbutin on activity of tyrosinases from mushroom and mouse melanoma. Biosci. Biotechnol. Biochem. 1995, 59, 143-144. [CrossRef] [PubMed]

86. Qin, L.; Wu, Y.; Liu, Y.; Chen, Y.; Zhang, P. Dual effects of alpha-arbutin on monophenolase and diphenolase activities of mushroom tyrosinase. PLOS ONE 2014, 9, e109398. [CrossRef]

87. Garcia-Jimenez, A.; Teruel-Puche, J.A.; Berna, J.; Rodriguez-Lopez, J.N.; Tudela, J.; Garcia-Canovas, F. Action of tyrosinase on alpha and beta-arbutin: A kinetic study. PLOS ONE 2017, 12, e0177330. [CrossRef] [PubMed]

88. Sugimoto, K.; Nishimura, T.; Nomura, K.; Sugimoto, K.; Kuriki, T. Inhibitory effects of alpha-arbutin on melanin synthesis in cultured human melanoma cells and a three-dimensional human skin model. Biol. Pharm. Bull. 2004, 27, 510-514. [CrossRef] [PubMed]

89. Sugimoto, K.; Nishimura, T.; Nomura, K.; Sugimoto, K.; Kuriki, T. Syntheses of arbutin-alpha-glycosides and a comparison of their inhibitory effects with those of alpha-arbutin and arbutin on human tyrosinase. Chem. Pharm. Bull. 2003, 51, 798-801. [CrossRef] [PubMed]

90. Sugimoto, K.; Nomura, K.; Nishimura, T.; Kiso, T.; Sugimoto, K.; Kuriki, T. Syntheses of alpha-arbutin-alpha-glycosides and their inhibitory effects on human tyrosinase. J. Biosci. Bioeng. 2005, 99, 272-276. [CrossRef] [PubMed]

91. Moon, Y.H.; Nam, S.H.; Kang, J.; Kim, Y.M.; Lee, J.H.; Kang, H.K.; Breton, V.; Jun, W.J.; Park, K.D.; Kimura, A.; et al. Enzymatic synthesis and characterization of arbutin glucosides using glucansucrase from Leuconostoc mesenteroides B-1299CB. Appl. Microbiol. Biotechnol. 2007, 77, 559-567. [CrossRef] [PubMed] 
92. Jun, S.Y.; Park, K.M.; Choi, K.W.; Jang, M.K.; Kang, H.Y.; Lee, S.H.; Park, K.H.; Cha, J. Inhibitory effects of arbutin-beta-glycosides synthesized from enzymatic transglycosylation for melanogenesis. Biotechnol. Lett. 2008, 30, 743-748. [CrossRef] [PubMed]

93. Rudeekulthamrong, P.; Kaulpiboon, J. Optimization of amylomaltase for the synthesis of alpha-arbutin derivatives as tyrosinase inhibitors. Carbohydr. Res. 2020, 494, 108078. [CrossRef] [PubMed]

94. Jiang, L.; Wang, D.; Zhang, Y.; Li, J.; Wu, Z.; Wang, Z.; Wang, D. Investigation of the pro-apoptotic effects of arbutin and its acetylated derivative on murine melanoma cells. Int. J. Mol. Med. 2018, 41, 1048-1054. [CrossRef] [PubMed]

95. Tokiwa, Y.; Kitagawa, M.; Raku, T. Enzymatic synthesis of arbutin undecylenic acid ester and its inhibitory effect on mushroom tyrosinase. Biotechnol. Lett. 2007, 29, 481-486. [CrossRef]

96. Xu, H.; Li, X.; Xin, X.; Mo, L.; Zou, Y.; Zhao, G.; Yu, Y.; Chen, K. Antityrosinase Mechanism and Antimelanogenic Effect of Arbutin Esters Synthesis Catalyzed by Whole-Cell Biocatalyst. J. Agric. Food Chem. 2021, 69, 4243-4252. [CrossRef]

97. Masyita, A.; Salim, E.; Asri, R.M.; Nainu, F.; Hori, A.; Yulianty, R.; Hatta, M.; Rifai, Y.; Kuraishi, T. Molecular modeling and phenoloxidase inhibitory activity of arbutin and arbutin undecylenic acid ester. Biochem. Biophys. Res. Commun. 2021, 547, 75-81. [CrossRef]

98. Yamashita-Higuchi, Y.; Sugimoto, S.; Matsunami, K.; Otsuka, H.; Nakai, T. Grevillosides J-Q, arbutin derivatives from the leaves of Grevillea robusta and their melanogenesis inhibitory activity. Chem. Pharm. Bull. 2014, 62, 364-372. [CrossRef] [PubMed]

99. Ghaffarzadeh, J.; Nasuhi Pur, F. Calixarbutin: A Novel Calixarene-based Potential Water-soluble Anti-tyrosinase Agent with High Anti-melanoma Activity. Iran. J. Pharm. Res. 2020, 19, 236-241.

100. Boissy, R.E.; Visscher, M.; DeLong, M.A. DeoxyArbutin: A novel reversible tyrosinase inhibitor with effective in vivo skin lightening potency. Exp. Dermatol. 2005, 14, 601-608. [CrossRef]

101. Chawla, S.; de Long, M.A.; Visscher, M.O.; Wickett, R.R.; Manga, P.; Boissy, R.E. Mechanism of tyrosinase inhibition by deoxyArbutin and its second-generation derivatives. Br. J. Dermatol. 2008, 159, 1267-1274. [CrossRef]

102. Anwar, A.I.; Asmarani, Y.; Madjid, A.; Patellongi, I.; Adriani, A.; As'ad, S.; Kurniadi, I. Comparison of 2\% deoxyarbutin and 4\% hydroquinone as a depigmenting agent in healthy individuals: A double-blind randomized controlled clinical trial. J. Cosmet. Dermatol. 2021. [CrossRef]

103. SCCS; Degen, G.H. Opinion of the Scientific Committee on Consumer Safety (SCCS)—Opinion on the safety of the use of beta-arbutin in cosmetic products. Regul. Toxicol. Pharmacol. 2015, 73, 866-867. [CrossRef]

104. Yang, Z.Q.; Wang, Z.H.; Zhang, T.L.; Tu, J.B.; Song, Y.; Hu, X.Y.; Li, G.G. The effect of aloesin on melanocytes in the pigmented skin equivalent model. Zhonghua Zheng Xing Wai Ke Za Zhi 2008, 24, 50-53. [PubMed]

105. SCCS; Degen, G.H. Opinion of the Scientific Committee on Consumer safety (SCCS)—Opinion on the safety of the use of deoxyarbutin in cosmetic products. Regul. Toxicol. Pharmacol. 2016, 74, 77-78.

106. Frias, M.A.; Winik, B.; Franzoni, M.B.; Levstein, P.R.; Nicastro, A.; Gennaro, A.M.; Diaz, S.B.; Disalvo, E.A. Lysophosphatidylcholinearbutin complexes form bilayer-like structures. Biochim. Biophys. Acta 2008, 1778, 1259-1266. [CrossRef] [PubMed]

107. Li, Y.; Li, F.; Cai, H.Y.; Chen, X.; Sun, W.; Shen, W.Y. Structural characterization of inclusion complex of arbutin and hydroxypropylbeta-cyclodextrin. Trop. J. Pharm. Res. 2016, 15, 2227-2233. [CrossRef]

108. Wen, A.H.; Choi, M.K.; Kim, D.D. Formulation of liposome for topical delivery of arbutin. Arch. Pharm. Res. 2006, 29, 1187-1192. [CrossRef] [PubMed]

109. Liang, K.; Xu, K.; Bessarab, D.; Obaje, J.; Xu, C. Arbutin encapsulated micelles improved transdermal delivery and suppression of cellular melanin production. BMC Res. Notes 2016, 9, 254. [CrossRef] [PubMed]

110. Huang, H.; Belwal, T.; Liu, S.B.; Duan, Z.H.; Luo, Z.S. Novel multi-phase nano-emulsion preparation for co-loading hydrophilic arbutin and hydrophobic coumaric acid using hydrocolloids. Food Hydrocoll. 2019, 93, 92-101. [CrossRef]

111. Ayumi, N.S.; Sahudin, S.; Hussain, Z.; Hussain, M.; Abu Samah, N.H. Polymeric nanoparticles for topical delivery of alpha and beta arbutin: Preparation and characterization. Drug Deliv. Transl. Res. 2019, 9, 482-496. [CrossRef]

112. Park, J.J.; Hwang, S.J.; Kang, Y.S.; Jung, J.; Park, S.; Hong, J.E.; Park, Y.; Lee, H.J. Synthesis of arbutin-gold nanoparticle complexes and their enhanced performance for whitening. Arch. Pharm. Res. 2019, 42, 977-989. [CrossRef]

113. Liao, A.H.; Ma, W.C.; Wang, C.H.; Yeh, M.K. Penetration depth, concentration and efficiency of transdermal alpha-arbutin delivery after ultrasound treatment with albumin-shelled microbubbles in mice. Drug Deliv. 2016, 23, 2173-2182. [CrossRef] [PubMed]

114. Aung, N.N.; Ngawhirunpat, T.; Rojanarata, T.; Patrojanasophon, P.; Opanasopit, P.; Pamornpathomkul, B. HPMC/PVP Dissolving Microneedles: A Promising Delivery Platform to Promote Trans-Epidermal Delivery of Alpha-Arbutin for Skin Lightening. AAPS PharmSciTech 2019, 21, 25. [CrossRef]

115. Aung, N.N.; Ngawhirunpat, T.; Rojanarata, T.; Patrojanasophon, P.; Pamornpathomkul, B.; Opanasopit, P. Fabrication, characterization and comparison of alpha-arbutin loaded dissolving and hydrogel forming microneedles. Int. J. Pharm. 2020, $586,119508$. [CrossRef] [PubMed]

116. Kim, H.S.; Kim, K.J.; Lee, M.W.; Lee, S.Y.; Yun, Y.H.; Shim, W.G.; Yoon, S.D. Preparation and release properties of arbutin imprinted inulin/polyvinyl alcohol biomaterials. Int. J. Biol. Macromol. 2020, 161, 763-770. [CrossRef]

117. Choi, S.; Park, Y.I.; Lee, S.K.; Kim, J.E.; Chung, M.H. Aloesin inhibits hyperpigmentation induced by UV radiation. Clin. Exp. Dermatol. 2002, 27, 513-515. [CrossRef] [PubMed]

118. Ertam, I.; Mutlu, B.; Unal, I.; Alper, S.; Kivcak, B.; Ozer, O. Efficiency of ellagic acid and arbutin in melasma: A randomized, prospective, open-label study. J. Dermatol. 2008, 35, 570-574. [CrossRef] 
119. Morag, M.; Nawrot, J.; Siatkowski, I.; Adamski, Z.; Fedorowicz, T.; Dawid-Pac, R.; Urbanska, M.; Nowak, G. A doubleblind, placebo-controlled randomized trial of Serratulae quinquefoliae folium, a new source of beta-arbutin, in selected skin hyperpigmentations. J. Cosmet. Dermatol. 2015, 14, 185-190. [CrossRef]

120. Jin, Y.H.; Lee, S.J.; Chung, M.H.; Park, J.H.; Park, Y.I.; Cho, T.H.; Lee, S.K. Aloesin and arbutin inhibit tyrosinase activity in a synergistic manner via a different action mechanism. Arch. Pharm. Res. 1999, 22, 232-236. [CrossRef]

121. Yang, Z.Q.; Wang, Z.H.; Tu, J.B.; Li, P.; Hu, X.Y. The effects of aloesin and arbutin on cultured melanocytes in a synergetic method. Zhonghua Zheng Xing Wai Ke Za Zhi 2004, 20, 369-371.

122. Hseu, Y.C.; Cheng, K.C.; Lin, Y.C.; Chen, C.Y.; Chou, H.Y.; Ma, D.L.; Leung, C.H.; Wen, Z.H.; Wang, H.M. Synergistic Effects of Linderanolide B Combined with Arbutin, PTU or Kojic Acid on Tyrosinase Inhibition. Curr. Pharm. Biotechnol. 2015, 16, 1120-1126. [CrossRef] [PubMed]

123. Hong, J.H.; Chen, H.J.; Xiang, S.J.; Cao, S.W.; An, B.C.; Ruan, S.F.; Zhang, B.; Weng, L.D.; Zhu, H.X.; Liu, Q. Capsaicin reverses the inhibitory effect of licochalcone A/beta-Arbutin on tyrosinase expression in b16 mouse melanoma cells. Pharmacogn. Mag. 2018, 14, 110-115. [PubMed]

124. Crocco, E.I.; Veasey, J.V.; Boin, M.F.F.D.; Lellis, R.F.; Alves, R.O. A Novel Cream Formulation Containing Nicotinamide 4\%, Arbutin 3\%, Bisabolol 1\%, and Retinaldehyde 0.05\% for Treatment of Epidermal Melasma. Cutis 2015, 96, 337-342.

125. Anwar, A.I.; Wahab, S.; Widita, W.; Nurdin, A.R.; Budhiani, S.; Seweng, A. Randomized control trial outcomes of tranexamic acid combination serum as a depigmenting agent for the use in healthy individuals. Dermatol. Ther. 2019, 32, e13146. [CrossRef] [PubMed]

126. Kalasho, B.D.; Minokadeh, A.; Zhang-Nunes, S.; Zoumalan, R.A.; Shemirani, N.L.; Waldman, A.R.; Pletzer, V.; Zoumalan, C.I. Evaluating the Safety and Efficacy of a Topical Formulation Containing Epidermal Growth Factor, Tranexamic Acid, Vitamin C, Arbutin, Niacinamide and Other Ingredients as Hydroquinone $4 \%$ Alternatives to Improve Hyperpigmentation: A Prospective, Randomize Controlled Split Face Study. J. Cosmet. Sci. 2020, 71, 263-290.

127. Polnikorn, N. Treatment of refractory melasma with the MedLite C6 Q-switched Nd:YAG laser and alpha arbutin: A prospective study. J. Cosmet. Laser Ther. 2010, 12, 126-131. [CrossRef]

128. Abbas, K.; Qadir, M.I.; Anwar, S. The Role of Melanin in Skin Cancer. Crit. Rev. Eukaryot Gene Expr. 2019, 29, 17-24. [CrossRef]

129. Smit, N.P.M.; Nieuwpoort, F.A.; Marrot, L.; Out, C.; Poorthuis, B.; van Pelt, H.; Meunier, J.R.; Pavel, S. Increased melanogenesis is a risk factor for oxidative DNA damage-Study on cultured melanocytes and atypical nevus cells. Photochem. Photobiol. 2008, 84, 550-555. [CrossRef]

130. Dumbuya, H.; Hafez, S.Y.; Oancea, E. Cross talk between calcium and ROS regulate the UVA-induced melanin response in human melanocytes. FASEB J. 2020, 34, 11605-11623. [CrossRef]

131. Suo, D.F.; Zeng, S.W.; Zhang, J.L.; Meng, L.H.; Weng, L.S. PM2.5 induces apoptosis, oxidative stress injury and melanin metabolic disorder in human melanocytes. Exp. Ther. Med. 2020, 19, 3227-3238. [CrossRef]

132. Perdomo, J.; Quintana, C.; Gonzalez, I.; Hernandez, I.; Rubio, S.; Loro, J.F.; Reiter, R.J.; Estevez, F.; Quintana, J. Melatonin Induces Melanogenesis in Human SK-MEL-1 Melanoma Cells Involving Glycogen Synthase Kinase-3 and Reactive Oxygen Species. Int. J. Mol. Sci. 2020, 21, 4970. [CrossRef]

133. Chang, S.P.; Huang, H.M.; Shen, S.C.; Lee, W.R.; Chen, Y.C. Nilotinib induction of melanogenesis via reactive oxygen speciesdependent JNK activation in B16F0 mouse melanoma cells. Exp. Dermatol. 2018, 27, 1388-1394. [CrossRef]

134. Denat, L.; Kadekaro, A.L.; Marrot, L.; Leachman, S.A.; Abdel-Malek, Z.A. Melanocytes as instigators and victims of oxidative stress. J. Investig. Dermatol. 2014, 134, 1512-1518. [CrossRef] [PubMed]

135. Jenkins, N.C.; Grossman, D. Role of Melanin in Melanocyte Dysregulation of Reactive Oxygen Species. Biomed. Res. Int. 2013, 2013, 908797. [CrossRef] [PubMed]

136. Nagapan, T.S.; Lim, W.N.; Basri, D.; Ghazali, A.R. Oral supplementation of L-glutathione prevents ultraviolet B-induced melanogenesis and oxidative stress in BALB/c mice. Exp. Anim. 2019, 68, 541-548. [CrossRef] [PubMed]

137. Arjinpathana, N.; Asawanonda, P. Glutathione as an oral whitening agent: A randomized, double-blind, placebo-controlled study. J. Dermatol. Treat. 2012, 23, 97-102. [CrossRef] [PubMed]

138. Gegotek, A.; Skrzydlewska, E. The role of transcription factor Nrf2 in skin cells metabolism. Arch. Dermatol. Res. 2015, 307, 385-396. [CrossRef] [PubMed]

139. Raghunath, A.; Sundarraj, K.; Nagarajan, R.; Arfuso, F.; Bian, J.; Kumar, A.P.; Sethi, G.; Perumal, E. Antioxidant response elements: Discovery, classes, regulation and potential applications. Redox Biol. 2018, 17, 297-314. [CrossRef]

140. Schafer, M.; Dutsch, S.; Keller, U.A.D.; Navid, F.; Schwarz, A.; Johnson, D.A.; Johnson, J.A.; Werner, S. Nrf2 establishes a glutathione-mediated gradient of UVB cytoprotection in the epidermis. Genes Dev. 2010, 24, 1045-1058. [CrossRef]

141. Shin, J.M.; Kim, M.Y.; Sohn, K.C.; Jung, S.Y.; Lee, H.E.; Lim, J.W.; Kim, S.; Lee, Y.H.; Im, M.; Seo, Y.J.; et al. Nrf2 Negatively Regulates Melanogenesis by Modulating PI3K/Akt Signaling. PLoS ONE 2014, 9, e96035. [CrossRef] [PubMed]

142. Chaiprasongsuk, A.; Onkoksoong, T.; Pluemsamran, T.; Limsaengurai, S.; Panich, U. Photoprotection by dietary phenolics against melanogenesis induced by UVA through Nrf2-dependent antioxidant responses. Redox Biol. 2016, 8, 79-90. [CrossRef]

143. Takebayashi, J.; Ishii, R.; Chen, J.B.; Matsumoto, T.; Ishimi, Y.; Tai, A. Reassessment of antioxidant activity of arbutin: Multifaceted evaluation using five antioxidant assay systems. Free Radic. Res. 2010, 44, 473-478. [CrossRef] [PubMed]

144. Tada, M.; Kohno, M.; Niwano, Y. Alleviation effect of arbutin on oxidative stress generated through tyrosinase reaction with L-tyrosine and L-DOPA. BMC Biochem. 2014, 15, 23. [CrossRef] 
145. Wu, L.H.; Li, P.; Zhao, Q.L.; Piao, J.L.; Jiao, Y.F.; Kadowaki, M.; Kondo, T. Arbutin, an intracellular hydroxyl radical scavenger, protects radiation-induced apoptosis in human lymphoma U937 cells. Apoptosis 2014, 19, 1654-1663. [CrossRef]

146. Seyfizadeh, N.; Tazehkand, M.Q.; Palideh, A.; Maroufi, N.F.; Hassanzadeh, D.; Rahmati-Yamchi, M.; Elahimanesh, F.; Borzoueisileh, S. Is arbutin an effective antioxidant for the discount of oxidative and nitrosative stress in Hep-G2 cells exposed to tert-butyl hydroperoxide? Bratisl. Med. J. Bratisl. Lek. Listy 2019, 120, 569-575. [CrossRef]

147. Ebadollahi, S.H.; Pouramir, M.; Zabihi, E.; Golpour, M.; Aghajanpour-Mir, M. The Effect of Arbutin on The Expression of Tumor Suppressor P53, BAX/BCL-2 Ratio and Oxidative Stress Induced by Tert-Butyl Hydroperoxide in Fibroblast and LNcap Cell Lines. Cell J. 2021, 22, 532-541.

148. Polouliakh, N.; Ludwig, V.; Meguro, A.; Kawagoe, T.; Heeb, O.; Mizuki, N. Alpha-Arbutin Promotes Wound Healing by Lowering ROS and Upregulating Insulin/IGF-1 Pathway in Human Dermal Fibroblast. Front. Physiol. 2020, 11, 586843. [CrossRef]

149. Zhang, B.; Zeng, M.; Li, B.; Kan, Y.; Wang, S.; Cao, B.; Huang, Y.; Zheng, X.; Feng, W. Arbutin attenuates LPS-induced acute kidney injury by inhibiting inflammation and apoptosis via the PI3K/Akt/Nrf2 pathway. Phytomedicine 2021, 82, 153466. [CrossRef]

150. Nalban, N.; Sangaraju, R.; Alavala, S.; Mir, S.M.; Jerald, M.K.; Sistla, R. Arbutin Attenuates Isoproterenol-Induced Cardiac Hypertrophy by Inhibiting TLR-4/NF-kappaB Pathway in Mice. Cardiovasc. Toxicol. 2020, 20, 235-248. [CrossRef] [PubMed]

151. Safari, H.; Zabihi, E.; Pouramir, M.; Morakabati, P.; Abedian, Z.; Karkhah, A.; Nouri, H.R. Decrease of intracellular ROS by arbutin is associated with apoptosis induction and downregulation of IL-1beta and TNF-alpha in LNCaP; prostate cancer. J. Food Biochem. 2020, 44, e13360. [CrossRef] [PubMed]

152. Matsuo, Y.; Ito, A.; Masui, Y.; Ito, M. A case of allergic contact dermatitis caused by arbutin. Contact Dermat. $2015,72,404-405$. [CrossRef] [PubMed]

153. Numata, T.; Tobita, R.; Tsuboi, R.; Okubo, Y. Contact dermatitis caused by arbutin contained in skin-whitening cosmetics. Contact Dermat. 2016, 75, 187-188. [CrossRef] [PubMed] 